\title{
SIMS U-Pb, Sm-Nd isotope and geochemical study of an arkosite-amphibolite suite, Peräpohja Schist Belt: evidence for ca. 1.98 Ga A-type felsic magmatism in northern Finland
}

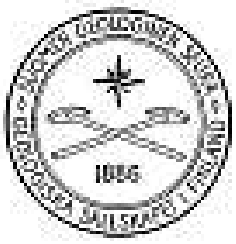

\author{
Eero Hanski ${ }^{1) *}$, Hannu Huhma ${ }^{2)}$ and Vesa Perttunen ${ }^{3)}$ \\ 1) Department of Geosciences, P.O. Box 3000, FIN-90014 University of Oulu, Finland \\ 2) Geological Survey of Finland, P.O. Box 96, FIN-02151 Espoo, Finland \\ 3) Geological Survey of Finland, P.O. Box 77, FIN-96101 Rovaniemi, Finland
}

\begin{abstract}
In the northern and north-eastern part of the Peräpohja Schist Belt, northern Finland, an extensive supracrustal rock unit has been identified which is composed of alternating amphibolitic and arkositic components. The amphibolites form layers whose thickness varies from one millimeter to some tens of meters, being most often a few tens of centimeters. They represent mafic tuff beds deposited concurrently with more abundant arkositic rocks. Most of the arkosites have a modal and major and trace element composition similar to that of $\mathrm{A}_{2}$-type granites. For example, they exhibit high LREE/HREE, negative Eu anomalies, and flat HREE and are moderately enriched in $\mathrm{Nb}, \mathrm{Zr}$, and $\mathrm{Y}$. The genesis of the arkosites is enigmatic as they show features supporting either a volcaniclastic or an epiclastic origin. In the latter case, they were derived via erosion of a source dominated by $\mathrm{A}_{2}$ type granitic rocks.

Previous conventional ID-TIMS and new SIMS U-Pb dating of zircons from two arkosite samples and one mica schist sample, all three picked from the northern part of the schist belt, indicate that these rocks contain a single population of zircons with an age of ca. 1975 Ma suggesting that they are among the youngest supracrustal rocks in the schist belt. In contrast, one mica schist sample from the western part of the belt revealed only the presence of Archean zircons. The samples do not differ markedly in terms of their $\mathrm{Nd}$ isotope composition as they all have a moderately negative $\varepsilon_{\mathrm{Nd}}(1900 \mathrm{Ma}$ ). Regardless of the genesis of the arkosites, their isotopic and geochemical data suggest a previously unknown occurrence of extensive A-type felsic magmatism at ca. $1.98 \mathrm{Ga}$, contemporaneously with some continental flood basalts. However, concrete evidence for this felsic A-type magmatism in the form of ca. $1.98 \mathrm{Ga}$ felsic plutonic rocks is virtually absent in the presently exposed Fennoscandian Shield.
\end{abstract}

Key words: metasedimentary rocks, arkosite, Peräpohja Belt, geochemistry, absolute age, $\mathrm{U} / \mathrm{Pb}, \mathrm{Sm} / \mathrm{Nd}$, zircon, Paleoproterozoic, northern Finland

\footnotetext{
* Corresponding author e-mail: ehanski@sun3.oulu.fi
} 


\section{Introduction}

Geological mapping performed in the northern and north-eastern part of the Paleoproterozoic Peräpohja Schist Belt in northern Finland has revealed the presence of a spectacular supracrustal rock unit composed of intervening felsic and mafic rocks. This composite arkosite-amphibolite suite has turned out be an extensive rock unit encountered over a length of ca. $100 \mathrm{~km}$ (Fig. 1). The rocks of the suite were first described by Perttunen et al. (1996) in the explanatory notes to the Rovaniemi map sheet. They assigned these rocks on that map sheet to the Korkiavaara Formation. They presented some geochemical data on K-rich arkositic rocks and discovered that geochemically these rocks resemble A-type granites (cf. Eby, 1992). This led them to conclude that the source region of the arkositic metasediments was dominated by this kind of granites. It thus seemed that, in contrast to the wide-spread ("Jatulian”) quartzitic metasediments of the Peräpohja Schist Belt (Perttunen, 1985; Vaasjoki \& Perttunen, 2001), the arkosites were not erosion products of the Archean basement complex on the southeastern side of the schist belt, for this complex is dominated by Na-rich TTG gneisses. This finding gave an impetus to determine the conventional ID-TIMS U-Pb age for zircon from an arkosite sample belonging to the Korkiavaara Formation (Perttunen \& Vaasjoki, 2001). Given the tectono-stratigraphic position of the dated rock unit between the "Jatulian-type" quartzites and "Kaleviantype” mica schists (Väänänen et al., 1997), the obtained age, ca. $1980 \mathrm{Ma}$, was unexpectedly young but, on the other hand, was in accordance with the anticipated provenance distinct from typical Archean basement rocks.

The multi-grain ID-TIMS data indicate that the sedimentation age of the arkosites is probably younger than ca. $1980 \mathrm{Ma}$. Traditionally, it has been thought that the youngest metasediments in the Karelian formations, including the Peräpohja Schist Belt, are represented by the "Kalevian" mica schists and associated black schists (e.g., Meriläinen, 1980). Lithologically and geochronologically, the arkosite-amphibolite suite is not easy to correlate with these metapelites or any previously defined lithostratigraphic unit in the Peräpohja Schist Belt. The youngest, pelitic metasediments in the schist belt have generally been regarded as correlative to the "lower Kalevian" (Perttunen \& Vaasjoki, 2001), and the presence of "upper Kalevian" marine metasediments have so far not been substantiated. The "upper Kalevian" is thought to be younger than the 1.95 to $1.97 \mathrm{Ga}$ ophiolitic complexes in eastern Finland as evidenced by the youngest detrital zircons found in these sedimentary rocks (Claesson et al., 1993). The depositional age suggested by the conventional zircon dating of the arkosite sample is interesting because it indicates the presence in the Peräpohja Schist Belt of rocks which would be time-correlative with the "upper Kalevian" rather than the "lower Kalevian" rocks. As discussed by Hanski (2001) and Hanski et al. (2001), the arkosite-amphibolite suite poses one of the most perplexing problems in the stratigraphy and geochronology of northern Finland. Even though the suite appears to be an essential part of the Peräpohja Schist Belt, it has not been included in the lithostratigraphic schemes of the belt that are based on the rock successions found in the well-known western part of the schist belt (Perttunen, 1985, 1989; Perttunen \& Hanski, 2003).

In this paper, we report $\mathrm{Nd}$ isotopic data and single zircon $\mathrm{U}-\mathrm{Pb}$ ages for arkositic and pelitic rocks from several parts of the schist belt. For SIMS (secondary ion mass spectrometry) zircon dating, we have chosen two arkositic samples from the arkosite-amphibolite suite and, for comparative purposes, two mica schist samples from the Paakkola Group, which has been thought to represent the uppermost metasediments of the Peräpohja Schist Belt. One of these metapelites is spatially closely associated with the Korkiavaara Formation arkosites, while the other is from the westernmost part of the schist belt and represents typical "Kalevian" metasediments. We also present geochemical data for arkosites and associated amphibolites.

A terminological note: arkositic sandstones and their metamorphosed equivalents, arkose quartzites 


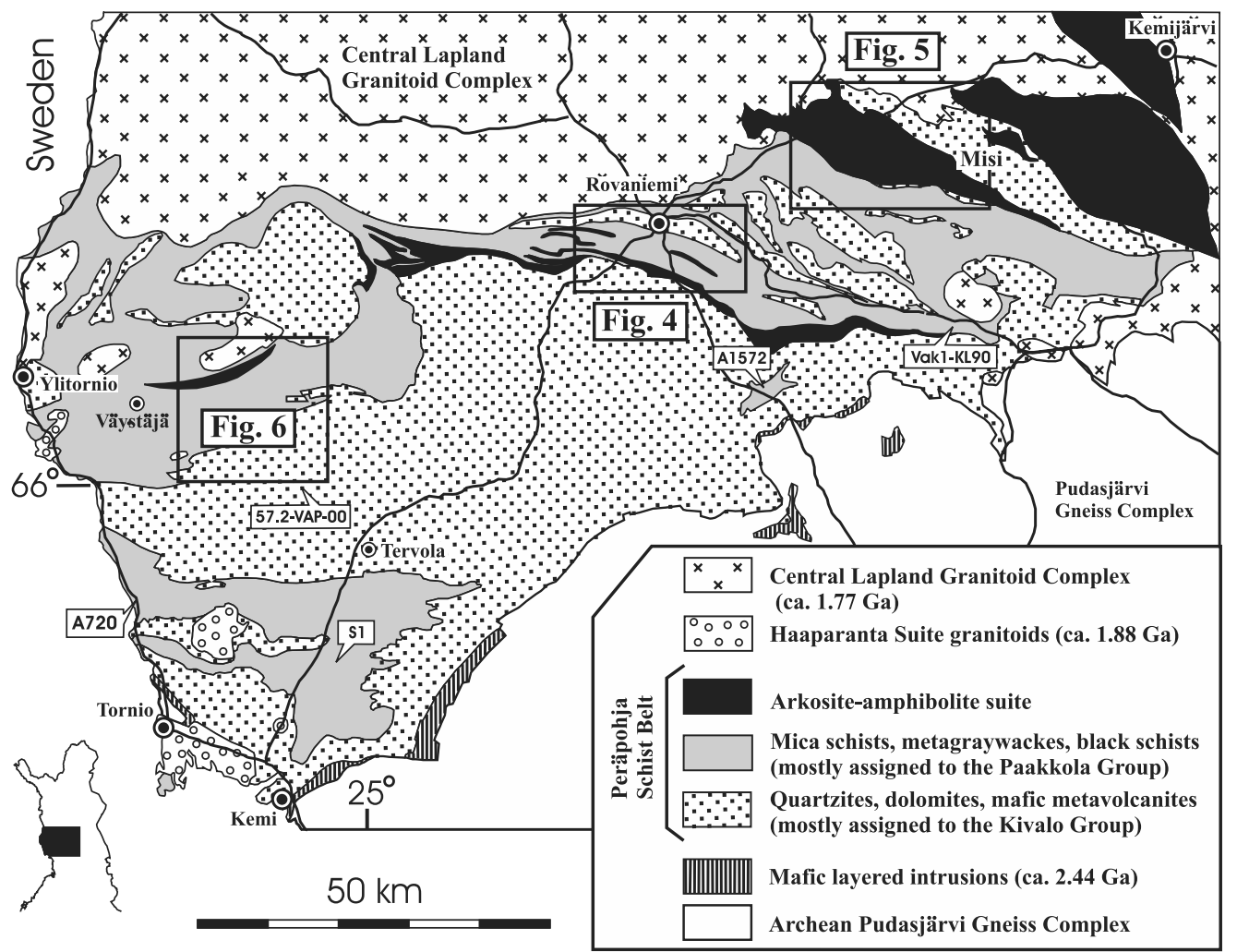

Fig. I. Major lithological units of the Paleoproterozoic Peräpohja Schist Belt. Also shown are the locations of Figs. 4, 5 and 6 and pelitic samples A702, SI,AI572,VakI-KL90 and arkose quartzite sample 57.2-VAP-00.

or arkosites, are highly feldspathic terrigeneous sedimentary rocks generally thought to have been derived by weathering of feldspar-rich plutonic rocks (Pettijohn, 1975). The felsic rocks of this study have been called arkosites implying a sedimentary origin, but the readers should bear in mind an alternative interpretation, which cannot be ruled out. As the associated amphibolites are interpreted as mafic tuffs in origin, the arkosites may have originated as tuffs as well.

\section{Geological background}

The supracrustal rocks of the Peräpohja Schist Belt form a classical "Karelian" sequence deposited unconformably on Archean gneissic basement, i.e., the Pu- dasjärvi Complex, which is located on the southeastern side of the schist belt. The time period of deposition of the rock succession is constrained, on the one hand, by the $2.44 \mathrm{Ga}$ mafic layered intrusions, which had been uplifted and partly eroded when the oldest sediments started to accumulate, and on the other hand, by the synorogenic monzonitic plutons of the ca.1.88 Ga Haaparanta Suite in the western part of the belt which crosscut the youngest pelitic metasediments of the belt. After the thermal and deformation peak at ca. $1.88 \mathrm{Ga}$, the supracrustal rocks were cut by postorogenic, ca. 1.77 Ga porphyritic granites, which abound at the northern margin of the belt (Lauerma, 1982; Perttunen \& Vaasjoki, 2001).

Traditionally, the supracrustal sequence of the Peräpohja Schist Belt has been divided into two ma- 
Table I. Lithostratigraphy of the Peräpohja Schist Belt, as established from the western part of the belt (after Perttunen \& Hanski, 2003), with addition of the Korkiavaara Formation on top. Age data taken from Huhma et al. (1990), Vaasjoki and Perttunen (200I), and this study.

\begin{tabular}{|l|l|l|l|}
\hline Group & Type Formation & Lithology & Age $(\mathrm{method})$ \\
\hline \multirow{2}{*}{ Paakkola Group } & Korkiavaara Formation & Arkosite and mafic tuff & $<1975 \pm 10 \mathrm{Ma}(\mathrm{U}-\mathrm{Pb})$ \\
& Väystäjä Formation & Mafic pillow lava, dolomite, black schist & $2050 \pm 8 \mathrm{Ma}(\mathrm{U}-\mathrm{Pb})^{1}$ \\
& Martimo Formation & Mica schist, metagreywacke, black schist & $>1880 \mathrm{Ma}(\mathrm{U}-\mathrm{Pb})^{2}$ \\
\hline Kivalo Group & Lamulehto Formation & Mafic tuff, tuffite & \\
& Rantamaa Formation & Dolomite & \\
& Hirsimaa Formation & Mafic tuff, tuffite & \\
& Poikkimaa Formation & Dolomite & $2090 \pm 70 \mathrm{Ma}(\mathrm{Sm}-\mathrm{Nd})$ \\
& Tikanmaa Formation & Mafic tuff, tuffite & $>$ ca. $2220 \mathrm{Ma}(\mathrm{U}-\mathrm{Pb})^{3}$ \\
& Kvartsimaa Formation & Orthoquartzite, dolomite & $2330 \pm 180 \mathrm{Ma}(\mathrm{Sm}-\mathrm{Nd})$ \\
& Jouttiaapa Formation & Amygdaloidal mafic metalava & $<2440 \mathrm{Ma}(\mathrm{U}-\mathrm{Pb})^{4}$ \\
\hline
\end{tabular}

Notes: 1) Age of a quartz porphyry; 2) minimum age based on cutting granodiorites; 3) minimum age based on cutting mafic sills; 4) maximum age based on underlying mafic layered intrusions.

jor rocks compartments, the older "Jatulian" rocks consisting mainly of quartzites, mafic volcanic rocks, and dolomites and the younger "Kalevian" rocks containing mica schists and black schists (Härme, 1949; Perttunen, 1980, 1985). Perttunen et al. (1995) adopted a formal lithostratigraphic nomenclature and divided the supracrustal rocks into two groups, the Kivalo and Paakkola Groups, corresponding to the former Jatulian and Kalevian rocks, respectively (see Hanski, 2001), and subdivided them into eleven formations. The stratigraphy was further refined by Perttunen \& Hanski (2003) who introduced a more detailed subdivision of the dolomite- and tuff-bearing upper part of the Kivalo Group. The current stratigraphic scheme of the Peräpohja Schist Belt, as established in the western part of the belt, is shown in Table 1. The geological structure of the belt becomes more complicated towards the north and east with the appearance of areas which have undergone higher degrees of deformation and metamorphism up to the development of local migmatization.

The Kivalo Group contains ten type formations, five being sedimentary and five volcanic in origin ( $\mathrm{Ta}-$ ble 1). The lowermost Sompujärvi Formation basal conglomerates are overlain by amygdaloidal mafic la- vas of the Runkaus Formation. The next and most voluminous unit of the schist belt is represented by the quartzitic metasediments of the Palokivalo Formation. These rocks have been cut by concordant, ca. $2.22 \mathrm{Ga}$ mafic layered sills (Perttunen \& Vaasjoki, 2001). Conventional ID-TIMS U-Pb isotope data indicate that the detrital zircons of the Palokivalo Formation are derived overwhelmingly or exclusively from the Archean basement (Perttunen \& Vaasjoki, 2001; Hanski et al., 2001). The mafic metavolcanites of the Jouttiaapa Formation form a thick pile of continental flood basalts with an age of $2090 \pm 70 \mathrm{Ma}$ as determined by the Sm-Nd method (Huhma et al., 1990). Orthoquartzites of the Kvartsimaa Formation separate the Jouttiaapa Formation from the upper part of the Kivalo Group formed by intervening units of carbonate rocks and mafic tuffs or tuffites (Perttunen \& Hanski, 2003). Carbonate rocks of the Poikkimaa and Rantamaa Formations display typical "Jatulian" positive carbon isotope anomalies (Karhu, 1993).

The Paakkola Group is largely composed of pelitic metasediments of the Martimo Formation, including metagraywackes, mica schists, and black schists. The other formation of the Paakkola Group, the Väystäjä Formation, is dominated by basaltic, partly pil- 
lowed volcanic rocks accompanied by black schists and some carbonate rocks (with a "normal" marine $\mathrm{C}$ isotope signature; Karhu, 2005). A felsic porphyritic rock occurring within the metavolcanites has been dated at $2050 \pm 8 \mathrm{Ma}$ (Perttunen \& Vaasjoki, 2001). The mutual age relationship between the Martimo and Väystäjä Formations is so far unclear.

Previously arkositic rocks have not been shown among the type formations in the lithostratigraphic columns of the Peräpohja Schist Belt (e.g., Perttunen et al., 1995). The reason for this is that lithologically, these rocks are not easy to correlate with any formation either in the Kivalo or Paakkola Group. In addition, there is no firm field evidence for the contact relationships. This is why the arkosite-bearing formations have been regarded as lithodemic units on some of the recent stratigraphic and geological maps constructed from the Peräpohja Schist Belt (Perttunen et al., 1995; Hanski, 2002).

Figure 1 shows the regional distribution in the Peräpohja Schist Belt of three major lithological units: 1) quartzites, dolomites, and mafic metavolcanic rocks (mostly assigned to the Kivalo Group), 2) pelitic metasediments (mostly assigned to the Paakkola Group), and 3) the arkosite-amphibolite suite. As shown by this map, the rocks of the arkosite-amphibolite suite occur in the northern and north-east- ern part of the schist belt. They are abundant in an area located some tens of kilometers NE of the town of Rovaniemi (Hanski, 2002). A still larger, poorly known area is located further eastward on the eastern side of the Misi belt. One bifurcation turns to the north close to the town of Kemijärvi and potentially joins the Central Lapland Greenstone Belt. Arkosites and associated amphibolites are also found as an EW-trending band south of Rovaniemi (Väänänen et al., 1997) and can be followed to the west until the Ylitornio area (Fig. 1). In all, the geographical distribution of the arkosite-amphibolite suite covers an area that extends for more than $100 \mathrm{~km}$ roughly in the EW direction.

\section{Field description and petrography}

Felsic, feldspar-rich rocks form volumetrically the dominant component in the arkosite-amphibolite suite, while the amphibolite component is subordinate. The amphibolites commonly occur as layers a few tens of centimeters in thickness. However, units up to tens of meters thick have been found, and very thin layers a few millimeters or only one millimeter thick are not rare (Fig. 2). The mafic layers have sharp contacts with arkositic rocks, and in the outcrop scale, each layer is normally uniform in thickness. Primary textures have
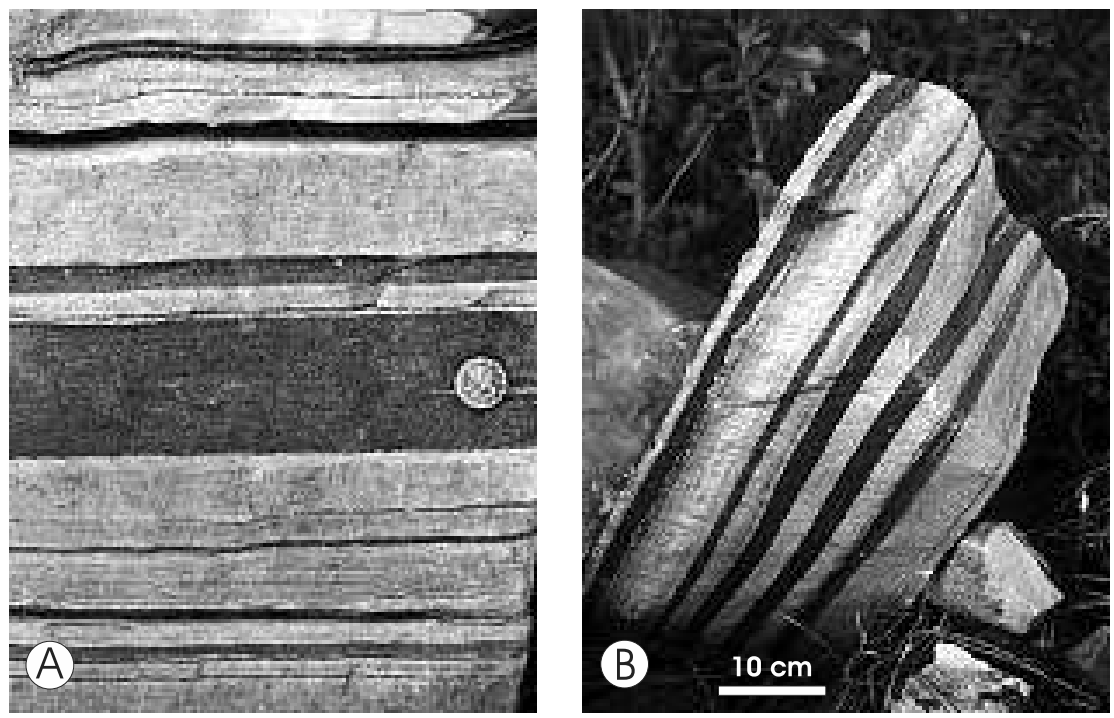

Fig. 2. Photos of an outcrop a) and a boulder b) showing interbedded mafic and felsic layers, Vikajärvi area. Coin diameter is $2.3 \mathrm{~cm}$. 

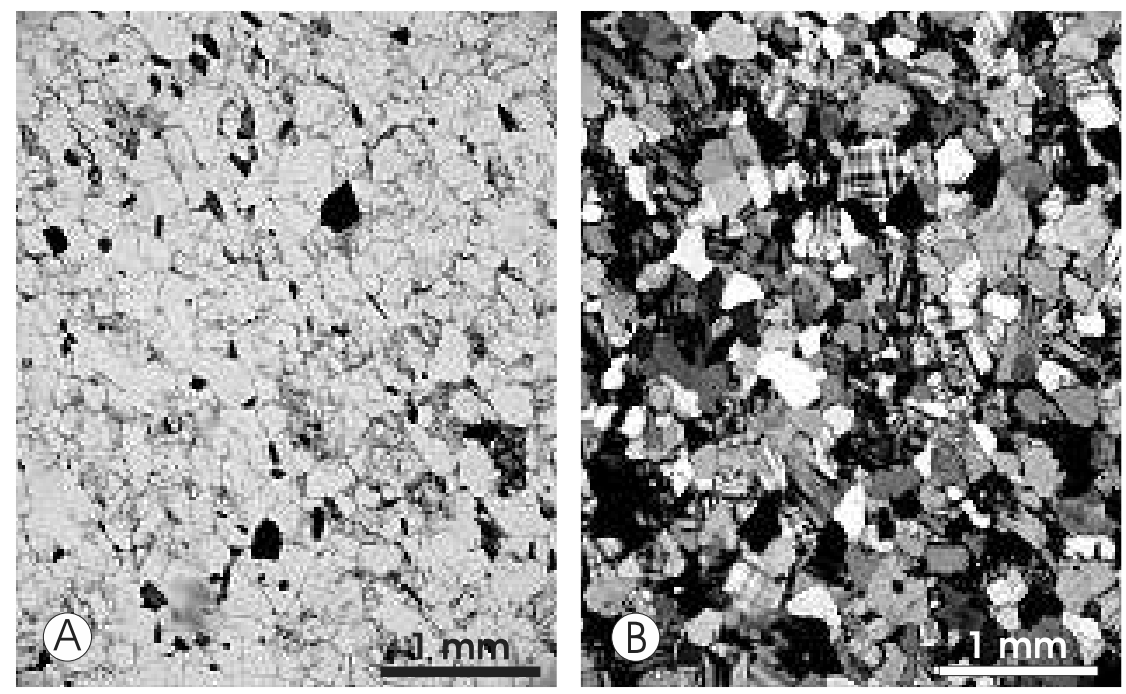

Fig. 3. Photomicrographs of a K-rich arkosite from the Vikajärvi area. a) Parallel nicols, b) Crossed nicols.

been destroyed by amphibolite facies metamorphism. Plagioclase and hornblende are the main minerals. They are often accompanied by biotite, particularly in the thinnest amphibolite layers, likely due to migration of potassium from the adjacent felsic rocks.

The presence of very thin, millimeter-scale amphibolite bands and the perfectly parallel, conformable nature of the mafic units in general demonstrate that the amphibolites do not represent sill-like injections of mafic magma but are supracrustal in origin. The most likely explanation for the genesis of the mafic rocks is that they represent beds of mafic tuff deposited concurrently with the arkositic rocks. A few mafic dikes have been found within the arkosites but they are conspicuously rare as compared to the frequency with which such dikes occur in the quartzites of the Peräpohja Schist Belt.

The arkosites are usually massive, poorly sorted rocks with a faintly recognizable bedding and a color of the weathered surface varying from greyish to pinkish. The field studies have not indicated the presence of current bedding or graded bedding. Also the absence of interlayers of feldspar-poor quartzites or distinctly more coarse metasediments, like conglomerates, is noteworthy. There are some biotite-bearing interlayers, which can be called mica gneisses. When arkosites are associated with thin amphibolites, the bedding of the composite rock is strikingly visible (Fig. 2). The general absence of features testifying mixing between the mafic and felsic materials indicates tranquil conditions of deposition without significant physical erosion or reworking by wave activity.

The arkosites are mainly composed of anhedral quartz, plagioclase, and microcline. Due to amphibolite facies recrystallization, no primary textures, such as clastic fabrics, are seen under the microscope (Fig. 3). Instead, the texture is granoblastic or crystalloblastic with a faint schistosity generated by accessory micas which are normally oriented parallel to the bedding. The average grain size of the felsic minerals is dependent on the degree of metamorphism and deformation, falling in the range of $0.2-0.4 \mathrm{~mm}$ in the least deformed rocks. Twinned potassic feldspar contains some perthite lamellae and is commonly clear, while plagioclase is usually somewhat turbid. Accessory minerals include biotite, magnetite, titanite, hornblende, chlorite, apatite, zircon, and in some cases muscovite. Magnetite occurs as small porphyroblasts normally up to $2 \mathrm{~mm}$, rarely $4 \mathrm{~mm}$ in size.

The arkosites are rather monotonous felsic rocks differing mainly due to the variable grain size caused by the variation in the degree of recrystallization. Within a few kilometers from the contact with the Central Lapland Granitoid Complex, the arkositic 


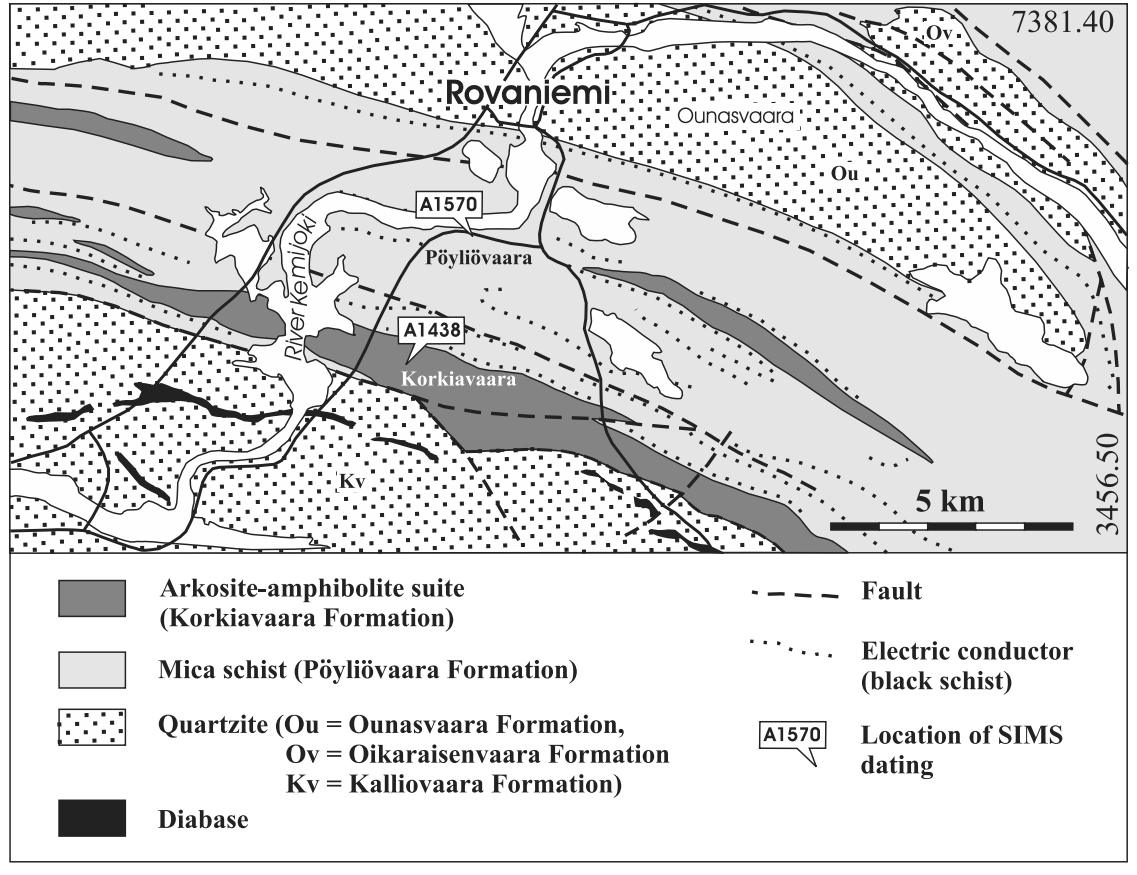

Fig. 4. Geological map of the Rovaniemi area (simplified afterVäänänen et al., 1997), showing the sampling sites of arkosite AI 438 at Korkiavaara (Korkiavaara Formation) and mica schist AI570 at Pöyliövaara (Pöyliövaara Formation). rocks may contain potassium feldspar porphyroblasts or change to more coarse-grained quartzofeldspathic gneisses (Hanski, 2002). In the latter case, the rocks may be difficult to distinguish from typical Archean tonalitic gneisses, for example. Nevertheless, ubiquitous thin amphibolite bands serve as a good identification mark, which allows the rocks of the arkosite-amphibolite suite to be recognized even in areas that have suffered from high degrees of migmatization and granitization.

There is another kind of variation stemming probably from the original composition of the rocks. On the northern flank of the Korkiavaara hill (Fig. 4), the Korkiavaara Formation contains rocks which Perttunen et al. (1996) called skarn arkosites. In addition to feldspars and quartz, these rocks contain diopside, epidote, carbonate, and tremolite.

\section{Sampling sites}

\section{I. Samples for zircon study}

Sample A1438 was picked from the type area of the Korkiavaara Formation located ca. $7 \mathrm{~km} \mathrm{SSW}$ of the town of Rovaniemi (Fig. 4) (Perttunen et al., 1996; Väänänen et al., 1997). The same arkosite sample was used for ID-TIMS multi-grain dating by Perttunen \& Vaasjoki (2001). As shown in Fig. 4, south of the arkosites of the Korkiavaara Formation, there are quartzites of the Kivalo Group representing the wide-spread "Jatulian” quartzites of the Peräpohja Schist Belt. Another major quartzite in Fig. 4 belongs to the Ounasvaara Formation. The area between these two quartzite units is mostly occupied by mica schists and black schists assigned to the Pöyliövaara Formation, but lenses or windows of arkosites and amphibolites of the Korkiavaara Formation have also been found (Fig. 4). The geological structure on the area is complicated due to faulting and thrusting. Due to a limited number of exposures, we have not been able to resolve the age relationship between the Pöyliövaara and Korkiavaara Formations using field evidence. Nor is there any evidence for the nature of the contact between the Korkiavaara Formation arkosites and the Kivalo Group quartzites, though we assume it to be tectonic. The deformation style of the rocks appears to change at this contact zone: the Kivalo Group quartzites have a gen- 


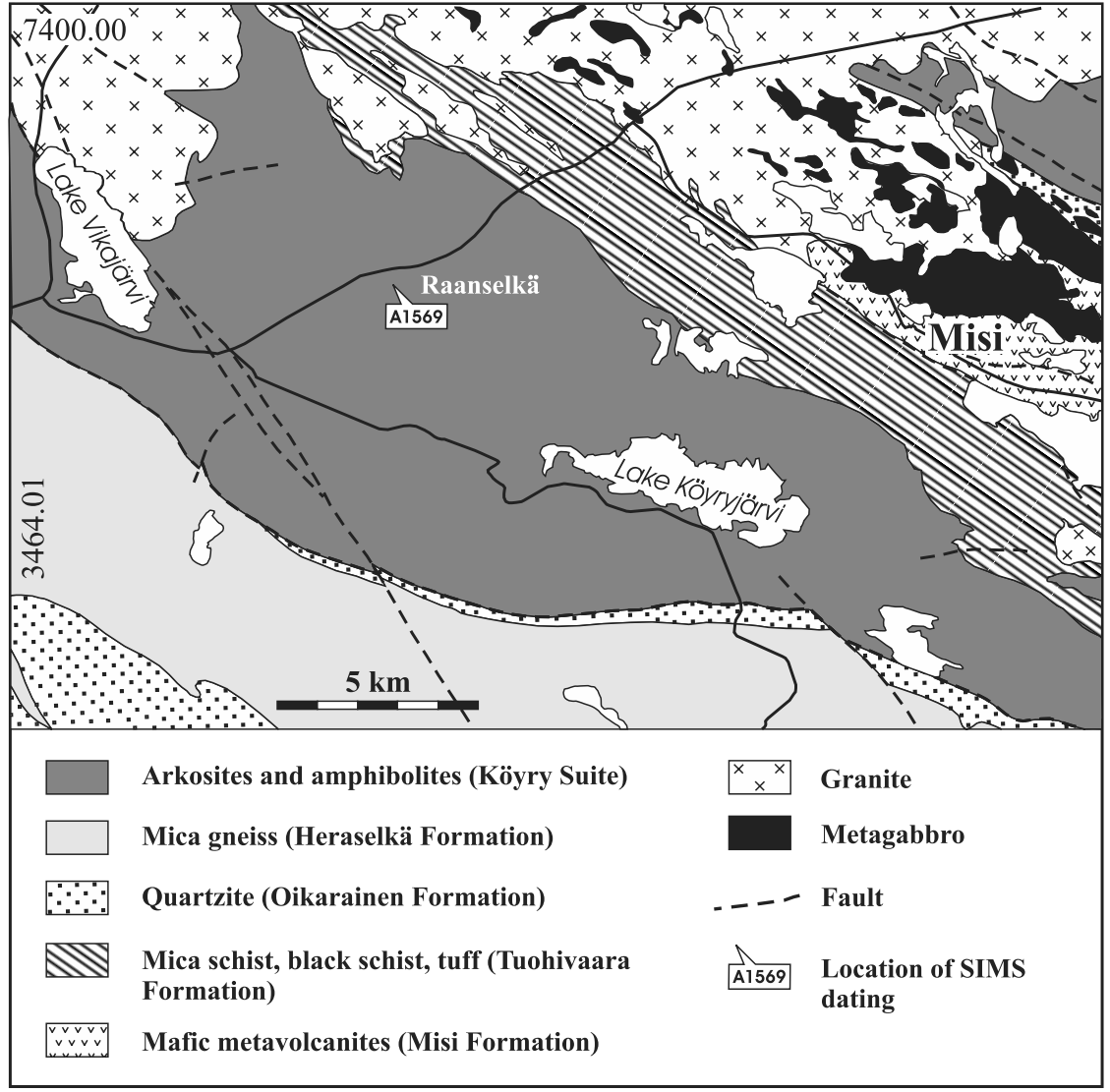

Fig. 5. Geological map from the Vikajärvi area, showing the sampling site of arkosite AI569 from Raanselkä (Köyry Suite) (simplified after Hanski, 2002). tly dipping, undulating bedding, whereas the bedding of the Korkiavaara and Pöyliövaara Formations dips more steeply and the rocks exhibit a distinct lineation dipping gently to NW.

Figure 4 also shows the sampling site of sample A1570, a schistose, plagioclase-rich mica schist from the Pöyliövaara Formation. Differing from the arkosites, it contains no or a small amount of potassic feldspar with potassium incorporated into biotite and to a lesser degree into muscovite. In addition to mica schists and mica gneisses, the Pöyliövaara Formation contains black schist interbeds that are revealed by electric conductors on aerogeophysical maps (see Fig. 4). The metamorphic grade increases towards the north so that the Pöyliövaara sample was picked from the sillimanite-cordierite zone, while the sampling site of the Korkiavaara arkosite is located close to the boundary between the andalusite and andalusite-cordierite zones (Väänänen et al., 1997).
Sample $\mathbf{A 1 5 6 9}$ is an arkosite very similar to sample A1438 from the Korkiavaara Formation. It was picked from Raanselkä located ca. $30 \mathrm{~km} \mathrm{NE}$ of the town of Rovaniemi (Fig. 5). Hanski (2002) regarded the arkosite-amphibolite assemblage in this area as a lithodemic unit and assigned it to the Köyry sedimentogenic-volcanogenic Suite, which represents one of the largest arkosite-amphibolite occurrences in the Peräpohja Schist Belt (see Fig. 1). This unit can be followed for ca. $50 \mathrm{~km}$ along strike in the SE direction and, at the sampling site, has a ca. $10 \mathrm{~km}$ wide cross-section on the surface (Hanski, 2002). The bedding of the arkosites is dipping to $\mathrm{N}$ or NE by 20 to 60 degrees. The Köyry Suite is truncated at its NW end by the Central Lapland Granitoid Complex (Fig. 5). Inclusions of arkositic gneiss and amphibolite are found in many places within the granites, apparently representing remnants of the Köyry Suite. 


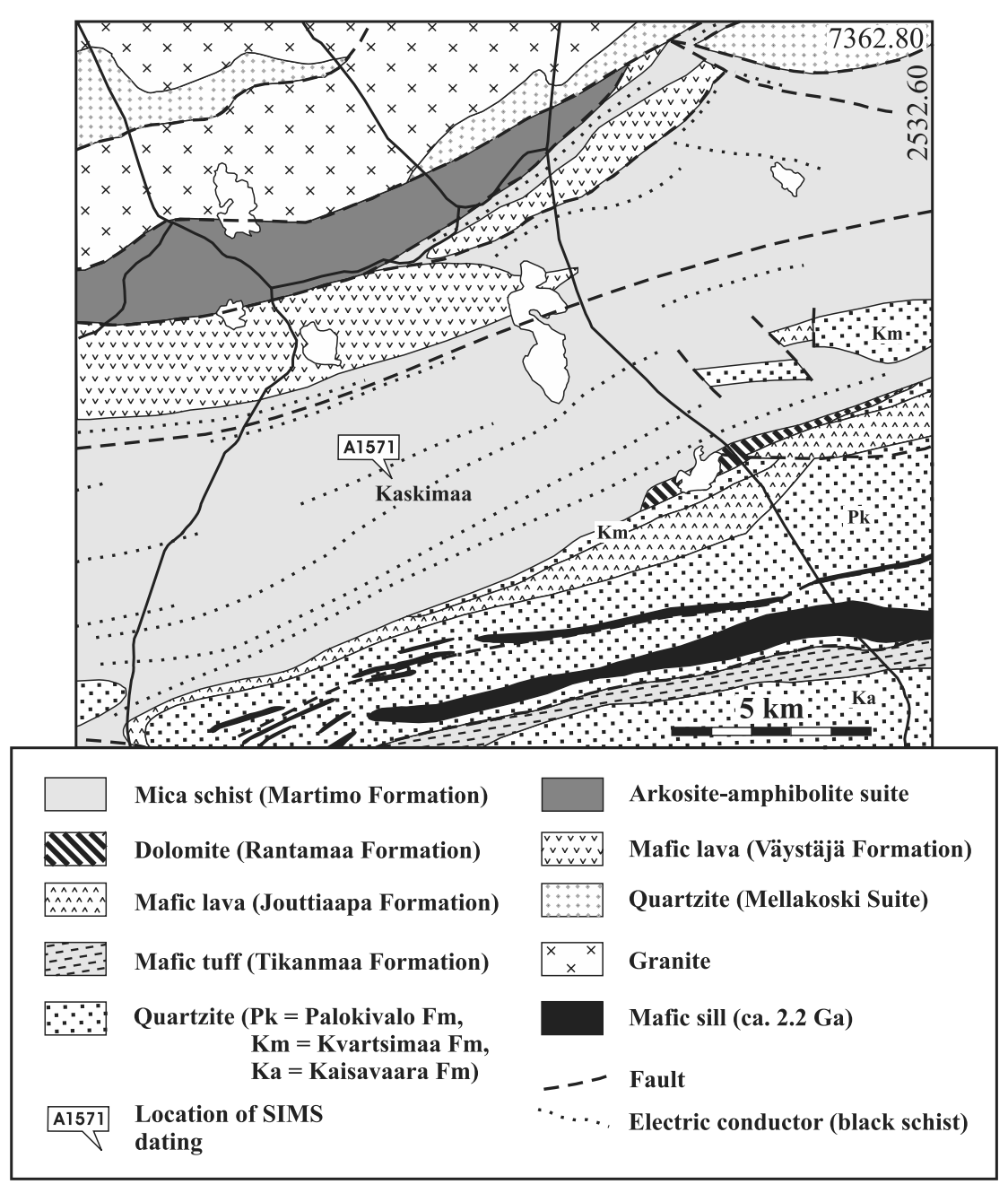

Fig. 6. Geological map of the Väystäjä area (simplified after Perttunen, 2002), showing the sampling site of metagraywacke AI57I at Kaskimaa (Martimo Formation).
As is shown by Fig. 5, on its north-eastern side the Köyry Suite is bounded by mafic tuffs and pelitic metasediments of the Tuohivaara Formation of the Misi iron ore belt (Hanski, 2002; Niiranen et al., 2003). There are only a few outcrops near the NE contact of the Köyry Suite and therefore its relationship to the supracrustal rocks of the Misi belt remains obscure. On the south-western side of the Köyry Suite, there are minor orthoquartzites and more voluminous, partly migmatitic mica gneisses of the Heraselkä Formation. The bedding and schistosity on both sides of the contact seem to be more or less parallel. Hence the arkosite-amphibolite formation appears to be conformable with the mica gneisses, but in the absence of outcrops of, or drillings through, the actual contact, no information is available on its exact nature, i.e., whether it is tectonic or sedimentary.

Sample A1571 was taken from Kaskimaa, which is located in the Väystäjä area some $70 \mathrm{~km}$ WSW of Rovaniemi (Fig. 6) (Perttunen, 2002). The sample represents a thick metagraywacke layer in the Martimo Formation. This formation is composed almost exclusively of pelitic metasediments. Bedding is distinct and often mica schists display turbidite beds up to one meter in thickness. Biotite, cordierite and andalusite porphyroblasts are common and ellipsoidal calcareous concretions can be found in thicker graywacke beds (Perttunen \& Hanski, 2003). Similarly to the Pöyliövaara Formation, the Martimo Formation contains black schist interbeds as indicated by electric conductors in Fig. 6. 


\subsection{Samples for $\mathrm{Nd}$ isotope study}

In addition to the four metasediment samples described above, five other samples were analyzed for $\mathrm{Sm}-\mathrm{Nd}$ isotopes from the Peräpohja Schist Belt. The locations of these samples are shown in Fig. 1. The sampling site of sample $\mathbf{A 7 2 0}$, representing the Martimo Formation, is situated at Napinmäki close to the Finnish-Swedish border in the westernmost part of the schist belt. The rock is a cordierite porphyroblastbearing mica schist, which was included in the U-Pb zircon study of Perttunen \& Vaasjoki (2001).

Sample $\mathbf{S 1}$ represents phyllite located very close to the Taivalkoski conglomerate in the SE part of the schist belt (Fig. 1). This conglomerate is a $80-\mathrm{m}$ thick, intraformational unit associated with turbiditic mica schists of the Martimo Formation. It contains pebbles composed mostly of quartzite and more rarely of quartz and felsic porphyry (Perttunen, 1991). A $\mathrm{Sm}-\mathrm{Nd}$ isotope analysis of sample $\mathrm{S} 1$ was earlier published by Huhma (1987). We determined a duplicate analysis of the same sample and also analyzed another sample, S1B, from the same locality.

Sample Vak1-KL90 is a mica gneiss picked from an outcrop close to the Vanttauskoski electric power plant in the eastern part of the schist belt (for the local geology, see Salonsaari, 1990). The rock belongs to the eastern continuation of the same mica schist unit (the Pöyliövaara Formation) from which sample A1570 was taken.

Sample A1572 was picked from a separate, small $(3 \times 10 \mathrm{~km})$ mica schist area located at Iso Palolampi ca. $30 \mathrm{~km} \mathrm{SE}$ of Rovaniemi in the central part of the schist belt (see Fig. 1). Here pelitic metasediments are surrounded by more typical "Jatulian" rocks of the Kivalo Group, including quartzites, dolomites, and mafic metavolcanic rocks. The rock type is finegrained mica schist containing cordierite, garnet and andalusite porphyroblasts. The sample was analyzed for $\mathrm{Nd}$ isotopes, though it was primarily taken for the ion probe study, but did not yield zircon.

The Kivalo Group quartzites are typically orthoquartzites and feldspar- or sericite-bearing quartzites. Feldspar-rich arkosic quartzites are also occasional- ly found, for example, at Kaisavaara (Perttunen \& Hanski, 2003). In order to compare with the arkosites of the arkosite-amphibolite suite, the $\mathrm{Sm}-\mathrm{Nd}$ isotopic composition was determined for one arkose quartzite, sample 57.2-VAP-00, from Kaisavaara (see Fig. 1).

\section{Analytical methods}

Whole-rock compositions were determined at the Geological Survey of Finland (GTK) using X-ray fluorescence analysis (XRF) for the major elements and part of the trace elements $(\mathrm{Cr}, \mathrm{Ni}, \mathrm{Ba}, \mathrm{Sr}, \mathrm{Pb}, \mathrm{Zr}, \mathrm{Zn}$, $\mathrm{Ga}, \mathrm{Sc}, \mathrm{V})$. Inductively coupled plasma mass spectrometry (ICP-MS) was used for the rare earth elements (REE) and some other trace elements (Th, $\mathrm{U}$, Ta, Nb, Rb, Th, U, Hf, Ta).

The crushing and mineral separation followed standard procedures at GTK and involved shaking table, heavy liquid (methylene di-iodide and clerici) and magnetic separation and handpicking. U-Th- $\mathrm{Pb}$ spot analyses of zircons were performed using a Cameca IMS1270 ion-microprobe at the Swedish Museum of Natural History, Stockholm (NORDSIM facility). The analytical procedure is described in Whitehouse et al. $(1997,1999)$. The spot diameter for the $4 \mathrm{nA}$ primary $\mathrm{O}_{2}^{-}$ion beam was ca. $30 \mu \mathrm{m}$, and oxygen flooding was used to improve the ionization of $\mathrm{Pb}$. Calibration of the $\mathrm{U} / \mathrm{Pb}$ ratio was based on analyses of the Geostandards zircon 91500, which has an age of $1065 \mathrm{Ma}$ (Wiedenbeck et al., 1995). Corrections for common $\mathrm{Pb}$ are based upon the measured ${ }^{204} \mathrm{~Pb}$ signal and the average terrestrial present-day $\mathrm{Pb}$ isotopic composition (Stacey \& Kramers, 1975). Data reduction was performed using the NORDSIM software written by M.J. Whitehouse, and age calculations were made using Isoplot/Ex 2.49 (Ludwig, 2001). Uncertainties in the weighted mean ages and concordia ages discussed in the text are given at $2 \sigma$ confidence level.

For Sm-Nd analyses, the whole-rock samples $\left(150 \mathrm{mg}\right.$ ) were dissolved in $\mathrm{HF}-\mathrm{HNO}_{3}$ for $48 \mathrm{~h}$ using sealed teflon bombs. Mixed ${ }^{149} \mathrm{Sm}-{ }^{150} \mathrm{Nd}$ spike was added to the sample prior to dissolution. After care- 
ful evaporation of fluorides, the residue was dissolved in $6 \mathrm{~N} \mathrm{HCl}$ and a clear solution was achieved. Samarium and neodymium were separated in two stages using a conventional cation-exchange procedure (7 $\mathrm{ml}$ of AG50Wx8 ion exchange resin in a bed of $12 \mathrm{~cm}$ length) and a modified version of the TeflonHDEHP (hydrogen di-ethylhexyl phosphate) method developed by Richard et al. (1976). The measurements were made in a dynamic mode on a VG SECTOR 54 mass-spectrometer using Ta-Re triple filaments. The ${ }^{143} \mathrm{Nd} /{ }^{144} \mathrm{Nd}$ ratio is normalized to ${ }^{146} \mathrm{Nd} /$ ${ }^{144} \mathrm{Nd}=0.7219$. The average value for the La Jolla standard is ${ }^{143} \mathrm{Nd} /{ }^{144} \mathrm{Nd}=0.511850 \pm 7(1 \sigma, \mathrm{n}=70$, triple filament measurements during 1995-2001). The $\mathrm{Sm} / \mathrm{Nd}$ ratio of the spike was calibrated against the Caltech mixed $\mathrm{Sm} / \mathrm{Nd}$ standard (Wasserburg et al, 1981). Based on duplicated analyses, the error in ${ }^{147} \mathrm{Sm} /{ }^{144} \mathrm{Nd}$ is estimated to be $0.4 \%$. The initial ${ }^{143} \mathrm{Nd} /{ }^{144} \mathrm{Nd}$ and $\varepsilon_{\mathrm{Nd}}$ values were calculated with the following parameters: $\lambda^{147} \mathrm{Sm}=6.54 \times 10^{-12} \mathrm{a}^{-1},{ }^{147} \mathrm{Sm} /$ ${ }^{144} \mathrm{Nd}=0.1966$ and ${ }^{143} \mathrm{Nd} /{ }^{144} \mathrm{Nd}=0.51264$ for the present-day CHUR. Depleted mantle model ages $\left(\mathrm{T}_{\mathrm{DM}}\right)$ are calculated according to DePaolo (1981). Measurement on the rock standard BCR-1 provided the following values: $\mathrm{Sm}=6.58 \mathrm{ppm}, \mathrm{Nd}=28.8$ $\mathrm{ppm},{ }^{147} \mathrm{Sm} /{ }^{144} \mathrm{Nd}=0.1380,{ }^{143} \mathrm{Nd} /{ }^{144} \mathrm{Nd}=0.51264$ \pm 0.00002 . The blank measured during analyses was $30-100 \mathrm{pg}$ for Sm and 100-300 pg for Nd.

\section{Geochemical results}

The arkositic samples chosen for geochemical analyses represent a wide geographical distribution. They were picked from the three separate areas which are illustrated in Figs. 4, 5 and 6. Results of the major and trace element analyses are shown in Table 2 . Previously Perttunen et al. (1996) noted that the sum of alkalies exceeds 6.5 wt.\% in the arkosites of the Korkiavaara Formation, whereas in the feldspar-rich arkose quartzites of the Kivalo Group, the total of alkalies is always below 6.5 wt. $\% . \mathrm{K}_{2} \mathrm{O} / \mathrm{Na}_{2} \mathrm{O}$ in the arkosites is usually higher than 1.0 and reaches values up to 7.0. The $\mathrm{SiO}_{2}$ and $\mathrm{Al}_{2} \mathrm{O}_{3}$ contents fall in the ranges of $68-76 \mathrm{wt} . \%$ and $12.5-14.0 \mathrm{wt} . \%$, respec- tively. The $\mathrm{CaO}$ content is usually low, most often around $1.0 \mathrm{wt} . \%$, with the exception of some samples in which it may reach $3.0 \mathrm{wt} . \%$ due to the presence of carbonate and/or amphibole. The CIPW-normative alkali feldspar content is high, normally between 50-62\%, reflecting the high modal feldspar content of the rocks. The total iron content $\left(\mathrm{FeO}_{\text {tot }}\right)$ normally falls between 1.4 and 2.7 wt. $\%$ and $\mathrm{MgO}$ is less than $1.0 \mathrm{wt} . \%$ resulting in cationic $\mathrm{Fe} /(\mathrm{Fe}+\mathrm{Mg})$ ratios of $0.66-0.93$. Thus the overall major element and modal composition of the arkosites is similar to that of granitic or rhyolitic rocks. More specifically, the arkositic rocks vary geochemically from metaluminous to peraluminous (ASI $=0.9$ to 1.1 ), though more often they are peraluminous. In the Q-P classification diagram of Debon \& LeFort (1983), they mostly plot in the fields of granite and adamellite and rarely in the fields of granodiorite or tonalite.

The analyzed arkosites are characterized by high $\mathrm{Ba}$ (300-1100 ppm) and Rb (130-250 ppm) and low Sr (20-140 ppm), all being features that are compatible with the observed high $\mathrm{K}_{2} \mathrm{O}$ and low $\mathrm{CaO}$ contents. Typically the rocks display relatively high contents of high-field strength elements like $\mathrm{Nb}(10-40 \mathrm{ppm})$, $\mathrm{Zr}$ (300-540 ppm) and Hf (6.5-11.5 ppm). They also have elevated concentrations of Y (20-65 ppm), Th (10-48 ppm), Ga (20-26 ppm), and total REE. There is a good mutual correlation among many incompatible trace elements such as $\mathrm{Zr}$, Hf, Th, $\mathrm{U}, \mathrm{Nb}$, and REE (excluding Eu).

Figure 7 shows primitive mantle-normalized spidergrams and chondrite-normalized REE patterns for six typical K-rich arkosites, which were picked from two areas, Vikajärvi and Väystäjä (Figs. 5, 6), separated ca. $100 \mathrm{~km}$ from each other. Despite the large distance, the rocks display very similar chemical compositions characterized by strong negative anomalies at $\mathrm{Eu}, \mathrm{Ba}, \mathrm{Sr}, \mathrm{Nb}, \mathrm{Ta}, \mathrm{P}$, and $\mathrm{Ti}$ and positive anomalies at $\mathrm{Pb}$ in Fig. 7a. The REE patterns are strongly enriched in LREE, while HREE show a flatter distribution (Fig. 7b). The negative Eu anomaly observed in the arkosites, with a total range of $0.27-0.63$ in terms of $\mathrm{Eu} / \mathrm{Eu}^{*}$, seems to have a positive correlation with the $\mathrm{K}_{2} \mathrm{O} / \mathrm{Na}_{2} \mathrm{O}$ ratio and total $\mathrm{REE}$ content. 
Table 2. Major and trace element analyses of arkosites (I-8) and amphibolites (9-10).

\begin{tabular}{|c|c|c|c|c|c|c|c|c|c|c|}
\hline & 1 & 2 & 3 & 4 & 5 & 6 & 7 & 8 & 9 & 10 \\
\hline $\mathrm{SiO}_{2}(\mathrm{wt} \%)$ & 75.77 & 68.14 & 72.90 & 72.80 & 73.60 & 74.00 & 75.10 & 74.60 & 49.08 & 47.50 \\
\hline $\mathrm{TiO}_{2}$ & 0.17 & 0.91 & 0.45 & 0.36 & 0.40 & 0.39 & 0.26 & 0.27 & 1.22 & 1.07 \\
\hline $\mathrm{Al}_{2} \mathrm{O}_{3}$ & 12.73 & 12.99 & 13.10 & 13.30 & 12.70 & 13.00 & 11.90 & 12.20 & 14.21 & 14.78 \\
\hline $\mathrm{FeO}_{\text {tot }}^{2}$ & 1.95 & 5.90 & 2.72 & 2.39 & 2.79 & 2.35 & 1.80 & 2.01 & 10.66 & 10.19 \\
\hline $\mathrm{MnO}$ & 0.02 & 0.19 & 0.05 & 0.05 & 0.06 & 0.04 & 0.03 & 0.03 & 0.19 & 0.21 \\
\hline $\mathrm{MgO}$ & 0.08 & 1.13 & 0.43 & 0.30 & 0.28 & 0.57 & 0.60 & 0.43 & 7.55 & 8.82 \\
\hline $\mathrm{CaO}$ & 1.07 & 2.66 & 1.28 & 0.91 & 1.08 & 1.16 & 0.68 & 0.39 & 10.08 & 9.81 \\
\hline $\mathrm{Na}_{2} \mathrm{O}$ & 3.83 & 3.31 & 3.14 & 3.20 & 0.83 & 2.54 & 1.81 & 2.78 & 2.59 & 2.67 \\
\hline $\mathrm{K}_{2} \mathrm{O}$ & 3.80 & 3.76 & 5.21 & 6.00 & 6.21 & 5.11 & 6.71 & 6.31 & 1.74 & 1.38 \\
\hline $\mathrm{P}_{2} \mathrm{O}_{5}$ & 0.01 & 0.22 & 0.08 & 0.04 & 0.06 & 0.04 & 0.03 & 0.03 & 0.15 & 0.08 \\
\hline $\mathrm{S}$ & 0.00 & & 0.00 & 0.00 & 0.00 & 0.01 & 0.00 & 0.71 & 0.04 & 0.00 \\
\hline LOI & 0.25 & 1.03 & & & 1.27 & 0.85 & 0.71 & & 0.70 & 0.96 \\
\hline Total & 99.67 & 100.24 & 99.36 & 99.35 & 99.28 & 100.05 & 99.64 & 99.75 & 98.20 & 97.46 \\
\hline $\mathrm{Cr}(\mathrm{ppm})$ & 9 & 8 & 0 & 0 & 11 & 23 & 13 & 4 & 266 & 428 \\
\hline $\mathrm{Ni}$ & 3 & & 0 & 0 & 1.4 & 7 & 2 & 2 & 94 & 157 \\
\hline Sc & 0.78 & 12 & 6.6 & 5.49 & 1.22 & 0 & 3.64 & 3.72 & 37.9 & 40.4 \\
\hline $\mathrm{V}$ & 9 & 22 & 41 & 0 & 22.6 & 42.4 & 23 & 14 & 261 & 240 \\
\hline $\mathrm{Zr}$ & 362 & 360 & 329 & 470 & 535 & 369 & 370 & 373 & 100 & 60 \\
\hline Hf & 9.34 & & 9.83 & 11.3 & & & & & 2.85 & 1.83 \\
\hline $\mathrm{Ba}$ & 883 & 880 & 495 & 541 & 763 & 485 & 607 & 490 & 170 & 235 \\
\hline $\mathrm{Rb}$ & 133 & 150 & 251 & 225 & 247 & 168 & 250 & 177 & 50.8 & 81.0 \\
\hline $\mathrm{Sr}$ & 93 & 130 & 61 & 35 & 41.6 & 105 & 14 & 17 & 151 & 180 \\
\hline $\mathrm{Ta}$ & 1.48 & & 2.42 & 3.55 & & & & & 0.46 & 0.24 \\
\hline $\mathrm{Nb}$ & 19.7 & & 28.3 & 46.2 & 46.7 & 42.7 & 42 & 46 & 6.53 & 4.21 \\
\hline Th & 19.8 & 16 & 47.9 & 35.8 & 26.4 & 38.2 & 30.1 & 6.12 & 2.50 & 0.65 \\
\hline $\mathrm{U}$ & 4.61 & 4.4 & 11.8 & 7.89 & 5.7 & 5.27 & 6.94 & 6.12 & 0.71 & 0.23 \\
\hline $\mathrm{Cu}$ & 1 & 50 & 0 & 0 & 0 & 29.4 & 14 & 4 & 53 & 8 \\
\hline $\mathrm{Cl}$ & 70 & & 120 & 110 & 46.4 & 74.4 & 50 & 30 & 330 & 160 \\
\hline Ga & 25 & & & & 20 & 24.3 & 24 & 25 & 19 & 22 \\
\hline $\mathrm{Pb}$ & 23 & & 36 & 32 & 35.5 & 34.9 & 41 & 29 & 40 & 20 \\
\hline Y & 49 & 56 & 54.1 & 74.2 & 64.9 & 47.9 & 63.3 & 62.8 & 24.1 & 20.5 \\
\hline $\mathrm{La}$ & 60.5 & 54 & 73.4 & 71.7 & 83.5 & 58.9 & 71.9 & 76.2 & 9.43 & 6.89 \\
\hline $\mathrm{Ce}$ & 122 & & 148 & 146 & 129 & 92.6 & 139 & 151 & 22.7 & 15.2 \\
\hline $\operatorname{Pr}$ & 13.5 & & 16 & 16.1 & & & 15.7 & 16.9 & 2.80 & 2.06 \\
\hline $\mathrm{Nd}$ & 50.6 & & 52.1 & 56.3 & & & 57.5 & 61.5 & 12.1 & 11.0 \\
\hline $\mathrm{Sm}$ & 9.27 & 8.4 & 9.06 & 11 & & & 10.9 & 12.3 & 3.15 & 2.79 \\
\hline $\mathrm{Eu}$ & 1.27 & & 0.96 & 1.19 & & & 0.98 & 1.22 & 0.99 & 0.92 \\
\hline $\mathrm{Gd}$ & 9.56 & & 9.16 & 11.4 & & & 11.3 & 12.8 & 3.91 & 3.54 \\
\hline $\mathrm{Tb}$ & 1.48 & & 1.4 & 1.87 & & & 1.79 & 1.97 & 0.58 & 0.57 \\
\hline Dy & 8.42 & & 8.48 & 11.3 & & & 10.4 & 11.4 & 4.11 & 3.63 \\
\hline Ho & 1.74 & & 5.35 & 7.37 & & & 6.26 & 6.46 & 0.80 & 0.75 \\
\hline $\mathrm{Er}$ & 5.09 & & 1.72 & 2.37 & & & 2.19 & 2.27 & 2.25 & 2.12 \\
\hline $\mathrm{Tm}$ & 0.75 & & 0.8 & 1.13 & & & 0.91 & 0.94 & 0.34 & 0.29 \\
\hline $\mathrm{Yb}$ & 5.11 & & 5.47 & 7.34 & & & 6.28 & 6.34 & 2.33 & 1.93 \\
\hline $\mathrm{Lu}$ & 0.73 & 0.74 & 0.79 & 1.06 & & & 0.95 & 0.97 & 0.31 & 0.27 \\
\hline
\end{tabular}

Samples (code, area, coordinates):

1 - 191-EJH-01, Raanselkä, X=7395.21, Y=3473.07; 2 - 60-RSH-85, Raanselkä, X=7393.22, Y=3473.50;

3 - 94001963, Raanselkä, X=7393.99, Y=3471.32; 4 - 94001978, Köyry, X=7386.04, Y=3485.26;

5 - 225.1-JON-92, Korkiavaara, $X=7373.96, Y=3441.35 ; 6$ - 39.2-VJK-92, Salmivaara, $X=7374.06, Y=3449.38$;

7 - R5/18.80, Väystäjä, X=7358.20, Y=22518.17; 8 - R7/16.60, Väystäjä, X=7357.83, Y=2517.35;

9 - 28-RSH-85, Raanselkä, X = 7393.44, Y = 3474.13; 10 - 99-PJV-01, Junkuaselkä, X = 7382.63, Y = 3488.83.

Notes: Analyses 3 and 4 provided by the lithogeochemistry project of the Geological Survey of Finland.

$\mathrm{La}, \mathrm{Sm}$, and Lu of sample 2 determined by INAA, La and Ce of sample 5 and 6 by XRF. 

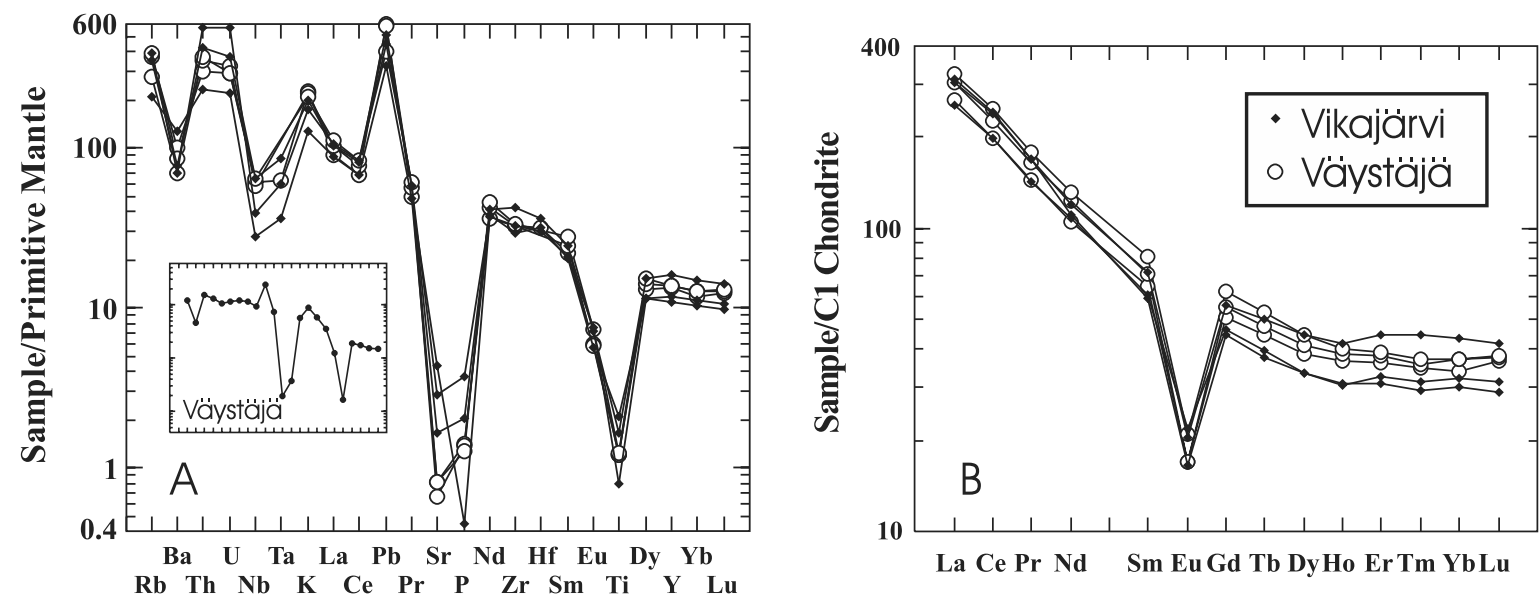

Fig. 7. Primitive mantle-normalized spidergrams a) and chondrite-normalized REE patterns b) for K-rich arkosites from the Vikajärvi and Väystäjä areas. Also shown as inset in Fig. 7A are analytical data for an acid porphyry from the Väystäjä Formation. Normalizing values taken from Sun \& McDonough (1989).
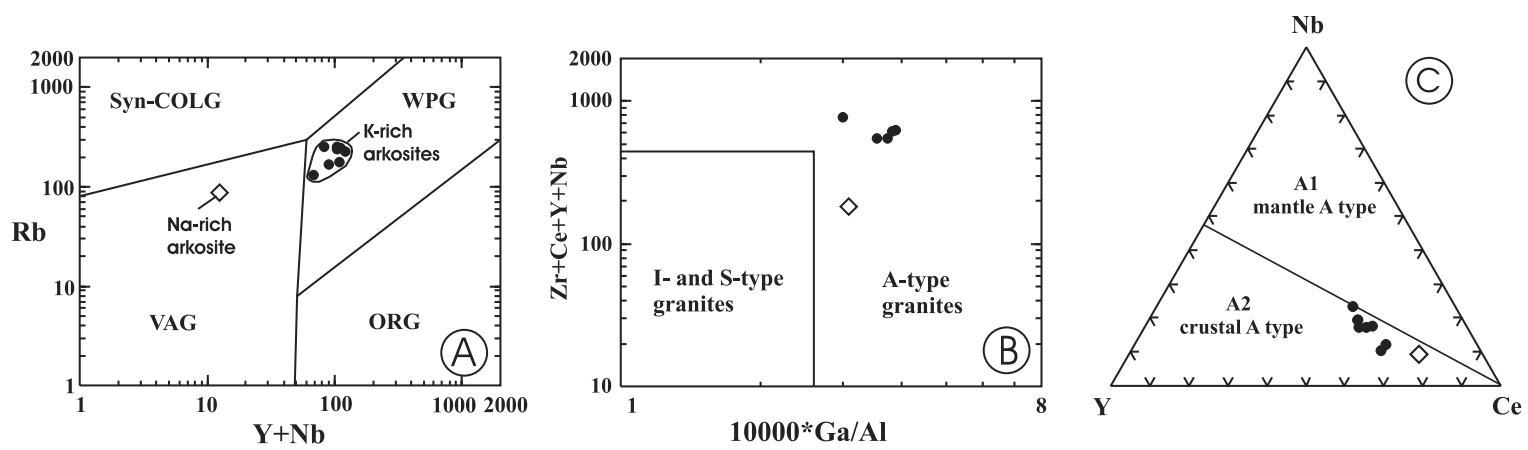

Fig. 8. Arkosite analyses plotted on different discrimination diagrams designed for felsic rocks. a) $\mathrm{Y}+\mathrm{Nb}$ vs. Rb diagram by Pearce et al. ( 1984$)$.WPG = within-plate granites, Syn-COLG = syncollisional granites, VAG = volcanic arc granites, ORG = orogenic granites; b) $\mathrm{Zr}+\mathrm{Ce}+\mathrm{Y}+\mathrm{Nb}$ vs. $\mathrm{Ga} / \mathrm{Al}$ diagram by Whalen et al. (1987); c) $\mathrm{Nb}-\mathrm{Ce}-\mathrm{Y}$ diagram by Eby (1992).

The enrichment of the arkosites in $\mathrm{Rb}, \mathrm{Nb}$, and $\mathrm{Y}$ is comparable to that of within-plate granites (Fig. 8a). High $\mathrm{Zr}, \mathrm{Ce}, \mathrm{Y}, \mathrm{Nb}$, and $\mathrm{Ga} / \mathrm{Al}$ place them in the field of A-type granites on the discrimination diagram of Whalen et al. (1987) (Fig. 8b). As illustrated in Fig. 8c, on the ternary Nb-Ce-Y diagram of Eby (1992), they plot in the field of $\mathrm{A}_{2}$-type granites due to their relatively low $\mathrm{Nb} / \mathrm{Ce}$ ratios (display a negative $\mathrm{Nb}$ anomaly in primitive mantle-normalized spidergrams, Fig. 7a). Bonjour \& Dabard (1991) drew attention to the fact that terrigenous sediments have a tendency to retain the $\mathrm{Nb} / \mathrm{TiO}_{2}$ ratio of the source rock in their chemical composition. Perttunen et al. (1996) noted that in their $\mathrm{Nb}-\mathrm{TiO}_{2}$ systematics, the arkosites differ from all other sedimentary rocks of the schist belt and hence have a unique provenance. In conclusion, the overall chemical signature of the arkosites is similar to that of the $\mathrm{A}_{2}$-type granites and provides evidence for the type of rock which dominated the potential source area.

All analyzed mafic interlayers are chemically subalkaline basalts. They show a relatively large variation in terms of the degree of fractionation with $\mathrm{MgO}$ falling between 8.6 and 3.8 wt. $\%, \mathrm{Mg} /(\mathrm{Mg}+\mathrm{Fe})$ ratios between 0.60 and 0.35 and $\mathrm{Cr}$ between 430 and 10 ppm. The $\mathrm{TiO}_{2}$ content increases with fractionation from 1.1 to 2.1 wt. $\%$, but $\mathrm{K}_{2} \mathrm{O}(0.4-1.6$ wt. $\%)$ shows a more random behavior and has evidently been mobile. The level of REE also varies but all samples have similar LREE-enriched primitive mantle-normalized (or chondrite-normalized) REE patterns with small 


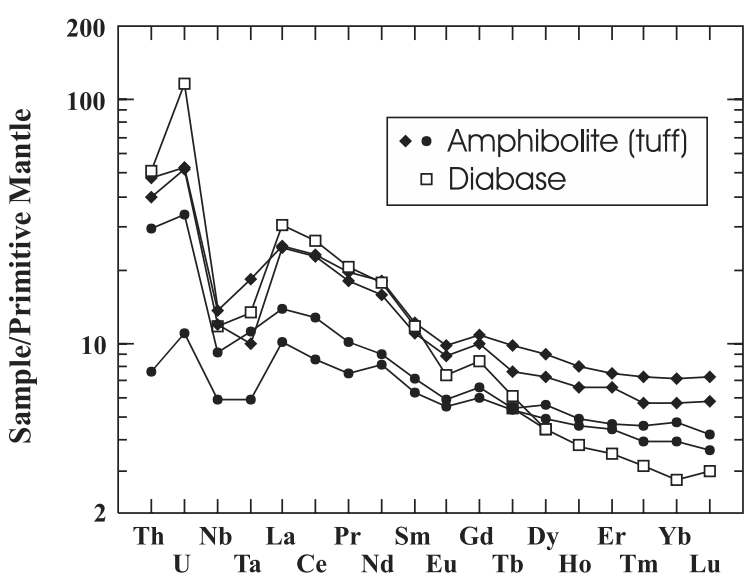

Fig. 9. Extended primitive mantle-normalized REE diagram for amphibolite interlayers and one diabase dike. Normalizing values taken from Sun \& McDonough (1989).

negative Eu anomalies (Fig. 9). As shown in Fig. 9, they also exhibit negative $\mathrm{Nb}$ and $\mathrm{Ta}$ anomalies most likely due to crustal contamination.

We analyzed one $30-\mathrm{cm}$-wide diabase dike which has penetrated into arkositic rocks in the Lake Köyryjärvi area (Fig. 5). It differs chemically from the amphibolite interlayers in having higher concentrations of the most incompatible trace elements but lower concentrations of moderately incompatible elements like $\mathrm{TiO}_{2}$, Y, and HREE (Fig. 9). Consequently, compared to the mafic tuffs, the diabase shows a steeper REE profile and was obviously generated from a different parental magma.

\section{Results of SIMS U-Pb analyses}

\section{I. Al438 (Korkiavaara Formation)}

The mineral separation of this sample yielded abundant zircon. Zircon population is relatively homogeneous and consists of pale, poorly rounded, subhedral grains. Back scattered electron images reveal that many grains contain embayments and rounded inclusions (Fig. 10a-c). Zoning is relatively poorly visible, and many grains look structureless or have irregular domains in BSE images. The U-Pb analytical data show a large variation in the $U$ contents (100-1800 ppm), and the amount of cracks obviously correlates with $U$ abundances.

Previously Perttunen \& Vaasjoki (2001) have published results of four ID-TIMS U-Pb analyses of zircon separates from sample A1438, scattering slightly around the reference chord with intercepts at ca. 1985 and $555 \mathrm{Ma}$. The three isotope compositions of the +200 mesh size fraction are exactly on a chord, giving an upper intercept age of $1975 \pm 7$ Ma.

The analytical data on zircons measured using SIMS are shown in Table 3. Ten U-Pb analyses were made on eight grains from sample A1438. The results are plotted on a concordia diagram in Fig. 11a together with the ID-TIMS data of Perttunen \& Vaasjoki (2001). One concordant analysis, labeled n129709a, gives a comparatively young age of $1912 \pm 4 \mathrm{Ma}$ (see the inset in Fig 11a). Excluding this analysis, an upper intercept age of $1973 \pm 11$ Ma can be calculated ( $\mathrm{n}=9$, Fig. 11a). If further two analyses that provide clearly discordant ages are excluded, a similar weighted mean ${ }^{207} \mathrm{~Pb} /{ }^{206} \mathrm{~Pb}$ age of $1974 \pm 12 \mathrm{Ma}$ is obtained with the rest seven concordant analyses. Thus only one analysis (n1297-09a) is distinct from the ca. 1.97 Ga population. This analysis was made from a very high-U domain in the core of grain 09 (see Fig. 10c). Analysis n1297-09b from the rim of this grain is clearly discordant with a ${ }^{207} \mathrm{~Pb} /{ }^{206} \mathrm{~Pb}$ age of $1943 \pm$ $34 \mathrm{Ma}$. Grain 09 has an appearance similar to that of the other zircon grains in this sample, and due to the high $\mathrm{U}$ content, one may speculate whether the U-Pb system still registers the primary crystallization time of that particular zircon. We can thus conclude that the SIMS results of sample A1438 indicate a primary magmatic age of ca. 1975 for the zircons. This result is in excellent agreement with the previous ID-TIMS data of Perttunen \& Vaasjoki (2001).

\subsection{Al569 (Köyry Suite)}

Zircons in the Raanselkä arkosite are significantly less abundant and smaller than those in the Korkiavaara sample, but otherwise the appearance of the population resembles that of the Korkiavaara zircons (Fig. 10d). Only five analyses were made but all of them are technically good and provide nearly concordant 

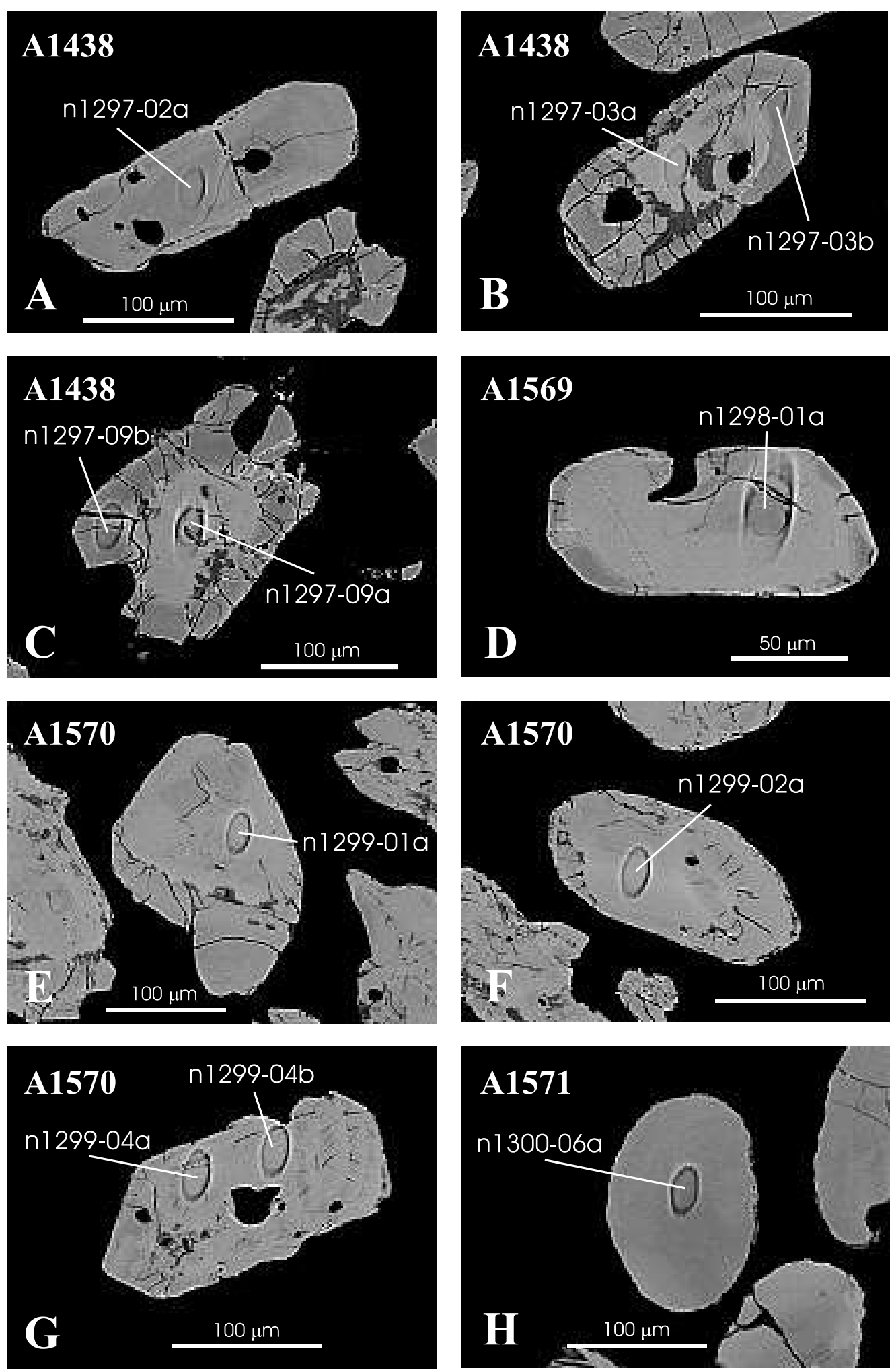

Fig. I0. Back scattered electron images of zircons. Zoned, ovoid areas show analyzed spots. a-c) A 4 438, arkosite, Korkiavaara; d) AI569, arkosite, Raanselkä; e-g) AI570, mica schist, Pöyliövaara; h) AI57I, metagraywacke, Kaskimaa. 


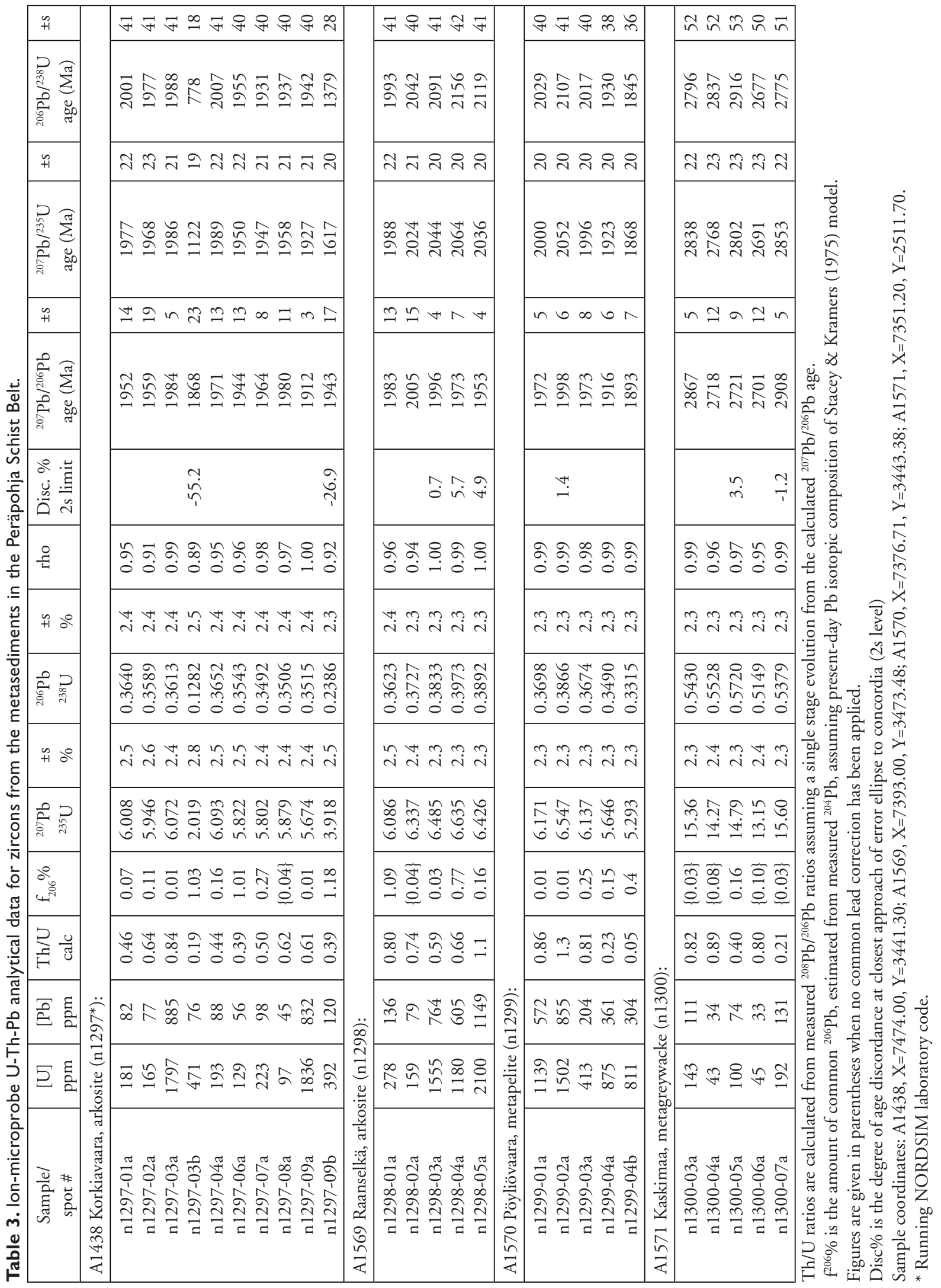



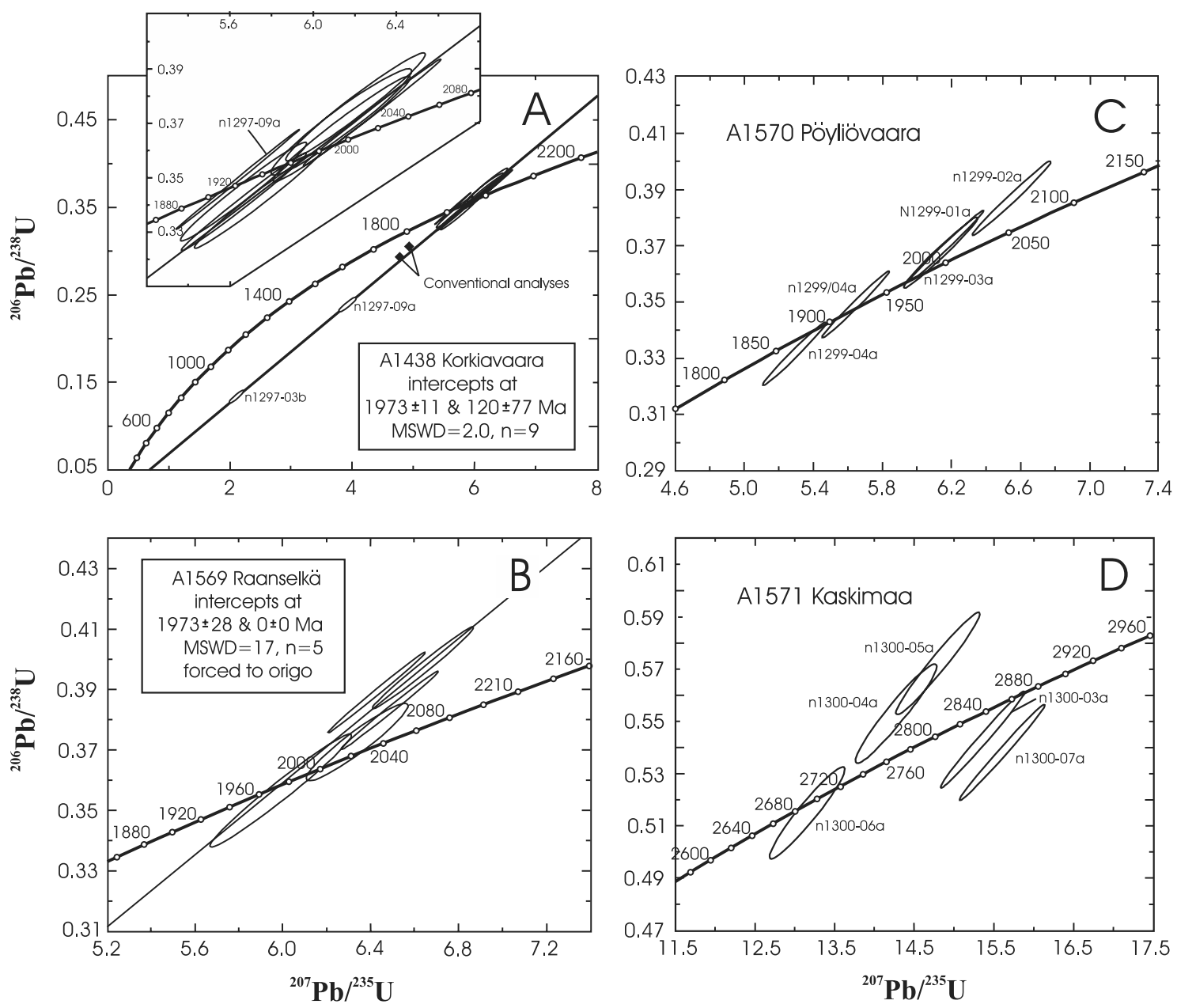

Fig. I I.U-Pb zircon concordia diagrams for metasediments. a) A I438, arkosite, Korkiavaara; b) AI 569, arkosite, Raanselkä; c) A 570, mica schist, Pöyliövaara; d) AI57I, metagraywacke, Kaskimaa. Error ellipses are plotted at I $\sigma$.

data (Fig. 11b). The ${ }^{207} \mathrm{~Pb} /{ }^{206} \mathrm{~Pb}$ ages range from 1952 \pm 8 to $2005 \pm 28 \mathrm{Ma}$, and provide a weighed mean age of $1973 \pm 28 \mathrm{Ma}(\mathrm{MSWD}=17)$. Although the data are sparse, the results are likely representative of the total population, since all the zircons in the mount look very similar to the analyzed ones.

\subsection{Al570 (Pöyliövaara Formation)}

The appearance of the separated zircons grains from the Pöyliövaara Formation mica schist resembles that of the zircons from the Korkiavaara Formation arkosite, though the former are slightly more rounded at edges (Fig. 10e-g). The five analyses made on four grains are technically good and provide concordant data (Fig. 11c). The ${ }^{207} \mathrm{~Pb} /{ }^{206} \mathrm{~Pb}$ ages for three grains fall between $1971 \pm 10$ and $1998 \pm 12 \mathrm{Ma}(2 \sigma)$, whereas the two analyses on the fourth grain (n129904) are slightly younger at $1916 \pm 12$ and $1893 \pm 14$ $\mathrm{Ma}$. The Th/U ratio in the youngest spot is distinctly low (0.05) compared to other data, which suggests an open system behavior and resetting of the U-Th$\mathrm{Pb}$ system during metamorphism.

\subsection{Al57I (Martimo Formation)}

The mineral separation of the metagraywacke from Kaskimaa yielded a very small amount of zircon. The 
Table 4. Sm and Nd concentration and isotope data on metasedimentary rocks from the Peräpohja Schist Belt.

\begin{tabular}{|c|c|c|c|c|c|c|c|c|c|c|}
\hline Sample & Location & Rock type & $\begin{array}{l}\mathrm{Sm} \\
\mathrm{ppm}\end{array}$ & $\begin{array}{l}\mathrm{Nd} \\
\mathrm{ppm}\end{array}$ & $\begin{array}{l}{ }^{147} \mathrm{Sm} / \\
{ }^{144} \mathrm{Nd}\end{array}$ & $\begin{array}{l} \pm 0.4 \% \\
0,004\end{array}$ & $\begin{array}{l}{ }^{143} \mathrm{Nd} / \\
{ }^{144} \mathrm{Nd}\end{array}$ & $2 \mathrm{se}$ & $\begin{array}{l}\varepsilon \mathrm{Nd} \\
(1900 \\
\mathrm{Ma}) \\
\end{array}$ & T-DM \\
\hline A143 & . & & 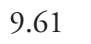 & 4 & 0.1185 & . & 27 & 10 & -2.7 & 2425 \\
\hline A1569 & lkä & rkosite & 11.28 & 57.03 & 0.1196 & 0.0005 & 0.511503 & 0.000010 & -3.4 & 2494 \\
\hline A1570 & Pöyliövaara & Mica schist & 9.56 & 48.84 & 0.1184 & 0.0005 & 0.511479 & 0.000010 & -3.6 & 2501 \\
\hline A1571 & Kaskimaa & letagreywacke & 2.82 & 12.3 & 0.1384 & 0.0006 & 0.511801 & 0.000010 & -2.2 & 2521 \\
\hline A720 & Napinmäki & Mica schist & 4.60 & 19.87 & 0.1398 & 0.0006 & 0.511751 & 0.000010 & -3.5 & 2684 \\
\hline S1 & Taivalkoski & Phyllite & 4.50 & 23.73 & 0.1146 & 0.0005 & 0.511462 & 0.000034 & -3.0 & 2435 \\
\hline S1, du & & & 4.64 & 25.00 & 0.1123 & 0.0005 & 0.511408 & 0.000011 & -3.5 & 2457 \\
\hline S1B & Taivalkoski & Phyllite & 3.58 & 17.53 & 0.1234 & 0.0005 & 0.511398 & 0.000010 & -6.4 & 2794 \\
\hline $\mathrm{S} 1 \mathrm{~B}, \mathrm{~d}$ & & & 3.48 & 17.10 & 0.1229 & 0.0005 & 0.511398 & & -6.3 & 2777 \\
\hline A1572 & Iso $\mathrm{P}$ & IVII & 4.8 & 23.89 & 0.1215 & 0.0005 & 0.511557 & 0.0 & -2.8 & 2455 \\
\hline Vak1-KL90 & Vanttauskoski & Mica gneiss & 4.65 & 24.16 & 0.1163 & 0.0005 & 0.511415 & 0.000010 & -4.3 & 2554 \\
\hline 57.2-VAP-00 & Kaisavaara & Arkose quartzite & 1.43 & 7.52 & 0.1147 & 0.0005 & 0.511002 & 0.000010 & -12.0 & 3164 \\
\hline
\end{tabular}

Errors in ${ }^{143} \mathrm{Nd} / 144 \mathrm{Nd}$ are $2 \mathrm{~s}$ in last significant digits

Sample coordinates: A720, $X=7323.55, Y=2503.70$; S1, $X=7316.50, Y=2532.40 ; A 1572, X=7355.52$, Y=3458.69; Vak1-

KL90, $X=7364.00, Y=3485.90 ; 57.2-V A P-00, X=7345.60, Y=2526.80$. For other samples, see Table 3.

zircon grains in this sample are very rounded and thus distinct from the zircons obtained from the previously discussed samples (Fig. 10h). The five U-Pb analyses made on this sample are concordant and provide ${ }^{207} \mathrm{~Pb} /{ }^{206} \mathrm{~Pb}$ ages from $2701 \pm 24$ to $2908 \pm 10$ $\mathrm{Ma}$ (Fig. 11d). The provenance of these zircons is thus very different from those of the other samples of this study, including the Pöyliövaara Formation metapelite. Our result is compatible with the previous ID-TIMS U-Pb zircon data from the Martimo Formation as reported by Perttunen \& Vaasjoki (2001). They also published a discordant Archean age for another metapelite sample, A720 Napinmäki, from the westernmost part of the Peräpohja Schist Belt. Similarly to sample A1571, the zircon grains in this sample are distinctly rounded.

\section{Sm-Nd isotope studies}

Samarium-neodymium analyses on whole-rock samples have been used to constrain the average provenance and crustal residence age of a sedimentary rock (e.g., McCulloch \& Wasserburg, 1978). The average provenance can be characterized by $\mathrm{T}_{\mathrm{DM}}$ model ages. However, they may be biased if metamorphic $\mathrm{Sm} / \mathrm{Nd}$ fractionation has taken place. Metamorphic effects at $1.8-1.9 \mathrm{Ga}$ are typically pronounced throughout the Karelian formations, and if these involved, for example, an increase in the $\mathrm{Sm} / \mathrm{Nd}$ ratio, the calculated model ages are unrealistically old. When discussing the origin of the crust that formed ca. at $1.9 \mathrm{Ga}$, it maybe more informative to use $\varepsilon_{\mathrm{Nd}}(1900 \mathrm{Ma})$ values than $\mathrm{T}_{\mathrm{DM}}$ model ages: Positive values suggest a major Paleoproterozoic source (the contemporaneous model depleted mantle has $\varepsilon_{\mathrm{Nd}}$ of ca. +4 ) for $\mathrm{Nd}$, whereas strongly negative values (e.g., -10) indicate an Archean crustal provenance.

Samarium-neodymium isotope and concentration data on the NORDSIM samples and some other metasedimentary rocks from the Peräpohja Schist Belt are shown in Table 4. Calculated $\mathrm{Nd}$ isotope evolution lines are shown Fig. 12. For reference, also shown are (mostly) published data from Karelian and Svecofennian metasediments in Finland.

The samples which indicate a major $1.98 \mathrm{Ga}$ zircon source, i.e., arkosites A1438 and A1569 and mica schist A1570, have relatively high REE contents and yield moderately negative $\varepsilon_{\mathrm{Nd}}(1900 \mathrm{Ma})$ values of $-2.7,-3.4$ and -3.6, respectively (at $1970 \mathrm{Ma}-2.0$, -2.7 , and -2.9$)$. This means that the average source 


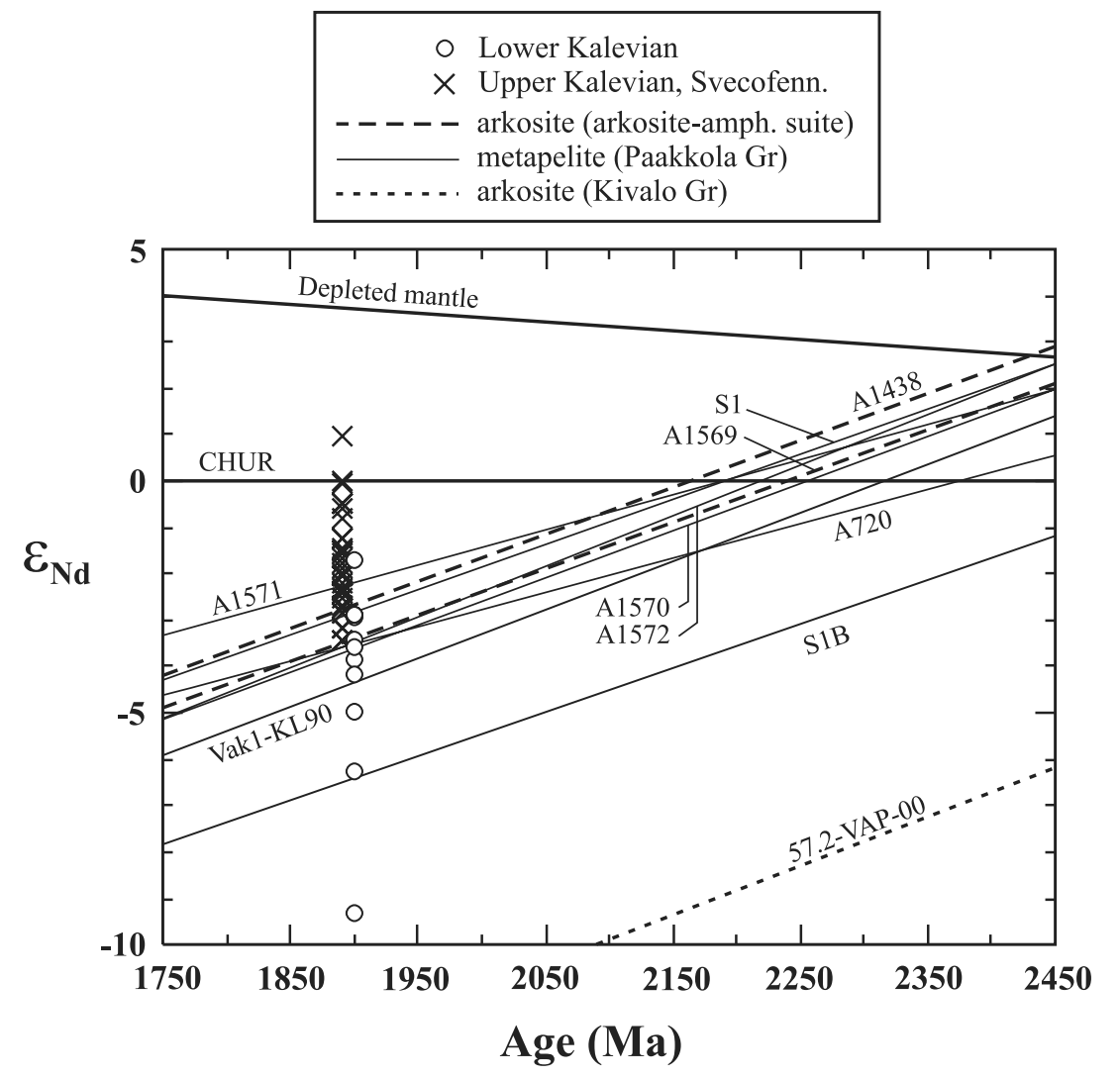

Fig. 12. Nd isotope evolution diagram for arkositic and pelitic rocks from the Peräpohja Schist Belt. Results from Lower Kalevian $\left(\varepsilon_{\mathrm{Nd}}\right.$ at $\left.1900 \mathrm{Ma}\right)$ and $\mathrm{Up}_{\mathrm{p}}$ per Kalevian and Svecofennian $\left(\varepsilon_{\mathrm{Nd}}\right.$ at $\left.1890 \mathrm{Ma}\right)$ pelitic metasediments are given for reference (data from Huhma, 1987; Lahtinen et al., 2002; unpublished data of GTK). Depleted mantle evolution after DePaolo (I98I). for these rocks could not have been particularly juvenile Paleoproterozoic crust, but rather involved a major contribution from older crustal material. This is compatible with the trace element composition of the arkosites which is similar to that of (crustal) $\mathrm{A}_{2}$ type granites. On the other hand, the initial $\varepsilon_{\mathrm{Nd}}$ values are clearly higher than that of the contemporaneous average Neoarchean upper crust which typically has $\varepsilon_{\mathrm{Nd}}$ around -10 (e.g., Huhma, 1986; O'Brien et al., 1993). This suggests 1) a mixed Archean and Paleoproterozoic source or 2) a major Paleoproterozoic ca. 1.98 Ga source, which had a slightly negative initial epsilon (due to previous crustal recycling).

Mica schist samples from the Paakkola Group yield $\varepsilon_{\mathrm{Nd}}(1900 \mathrm{Ma})$ values in the range of -2.2 to -4.3 (except sample S1B; Huhma, 1987), which are typical values for many "Lower Kalevian" metasediments (Fig. 12). Thus, in spite of the major difference in the zircon provenance, there is no difference in $\varepsilon_{\mathrm{Nd}}$ between the samples from the Martimo and
Korkiavaara Formations. The REE content in the rocks of the Martimo Formation is lower, and especially the Kaskimaa and Napinmäki samples have relatively high $\mathrm{Sm} / \mathrm{Nd}$ ratios. It is conceivable that the rocks of the Martimo Formation had a significant mafic component in their source. This is supported by the relatively high $\mathrm{MgO}$ and $\mathrm{Cr}$ contents, averaging 4.6 wt.\% and $210 \mathrm{ppm}$, respectively, that have been measured for mica schist and black schist samples from the Martimo Formation (Perttunen \& Hanski, 2003).

Very distinct from the previous samples is the Kaisavaara arkose quartzite (57.2-VAP-00) from the Kivalo Group, which gives $\varepsilon_{\mathrm{Nd}}(1900 \mathrm{Ma})$ of -12 and $\mathrm{T}_{\mathrm{DM}}$ of $3.16 \mathrm{Ga}$. This is consistent with the predominant or exclusive Archean provenance of the Kivalo Group quartzites as also suggested by detrital zircon data (Perttunen \& Vaasjoki, 2001).

The $\varepsilon_{\mathrm{Nd}}(1900 \mathrm{Ma})$ value of -2.8 measured for the Iso Palolampi metapelite sample A1572 is similar to 
those obtained for the Korkiavaara and Martimo Formations and suggests a significant Paleoproterozoic component in the source.

\section{Discussion and conclusions}

In order to make reliable constraints on the age of deposition of a sedimentary rock using detrital zircons, there should be several analyses of the youngest population to support the age. For 15 zircons grains of the total of 17 which were analyzed from samples A1438, A1569, and A1570, representing the Korkiavaara and Pöyliövaara Formations and the Köyry lithodemic Suite, SIMS yielded a very narrow range of ${ }^{207} \mathrm{~Pb} /{ }^{206} \mathrm{~Pb}$ ages with an average of $1975 \pm 10 \mathrm{Ma}$. Although the total number of the analyzed grains is small, all zircons in the separates of these samples display a similar, poorly rounded morphology. This, together with the identical age obtained by the ID-TIMS method, suggests that the zircons in these three samples form a single Paleoproterozoic population or, at least, is overwhelmingly dominated by such a population. Three ${ }^{207} \mathrm{~Pb} /{ }^{206} \mathrm{~Pb}$ ages, obtained from high- $\mathrm{U}$ or low- $\mathrm{Th} / \mathrm{U}$ domains of two zircon grains and varying from 1893 $\pm 14 \mathrm{Ma}$ to $1916 \pm 12 \mathrm{Ma}$, are considered to record post-depositional isotopic disturbance. Hence, assuming that the arkosites are epiclastic rocks, it is probably safe to state that the deposition of these rocks took place after ca. $1.98 \mathrm{Ga}$. On this basis, the arkosite-amphibolite suite is tentatively placed on top of the lithostratigraphy of the Peräpohja Schist Belt (Table 1).

The U-Pb age results from the three samples discussed above, coming from the northern part of the Peräpohja Schist Belt, provide strong evidence for the existence of abundant felsic crust at ca. 1.98 Ga. In contrast, the mica schist sample A1571 from the western part of the belt, representing the Martimo Formation, seems to contain a small amount of highly rounded zircons which were derived mostly or exclusively from the Archean basement.

The $\mathrm{Nd}$ isotopic compositions do not discriminate between the two rock groups with different zircon sources but all samples yielded moderately negative $\varepsilon_{\mathrm{Nd}}(1900 \mathrm{Ma})$ values. It is conceivable that the meta- graywackes of the Martimo Formation have a major zircon-poor Paleoproterozoic (mafic) source or that the zircons derived from this source were too small to be caught by mineral separation. Apparently, the small amount of the rounded, recycled Archean zircons was derived from some exotic sources compared to the main provenance, e.g. from the Kivalo Group quartzites (Perttunen \& Vaasjoki, 2001), which did not contribute much to the Sm-Nd budget.

The hypothesis that the arkosites were originally epiclastic sediments equivalent to arkosic sandstones seems to be natural but, as discussed below, it has some weaknesses. The hypothesis is supported by the same type of zircon, both in terms of morphology and age, found in the Korkiavaara Formation arkosite and Pöyliövaara Formation mica schist. This suggests that at least the zircon grains share the same genesis in these two formations. The skarn-bearing arkosites are also in favor of a sedimentary origin as they may represent rocks which were originally carbonate-bearing feldspar-rich sediments. The immaturity of the arkositic rocks and the presence of mafic volcanic interlayers suggest little or no chemical fractionation during weathering, short transportation distances, and a rapid rate of sedimentation, which took place somewhere in the time interval between 1.98 and $1.88 \mathrm{Ga}$. Major problems of this interpretation are the single population of zircon, the massive appearance of the arkosites, and the lack of current bedding or conglomeratic interbeds. The geochemistry, zircon data, and large volume of the rocks suggest an extensive, more or less monolithic granitic source, for which there seems to be no field evidence in the known bedrock of the shield (see below).

An alternative interpretation is that the arkosites may represent volcanic rocks, namely felsic tuffs. Subaerial deposition of volcanic ash would readily account for the homogeneous appearance of the arkosic rocks, lack of current bedding, and thinly laminated intervening of undisturbed mafic and felsic layers (see Fig. 2). It would also be compatible with the uniform age and the non-rounded, irregular form of the zircons. This explanation would imply the existence of bimodal continental volcanism at ca. 1.98 Ga. No 
volcanic textures are seen in the felsic rocks, but these may have been destroyed during metamorphic recrystallization or even by earlier zeolitization. Another problem in the volcanic hypothesis is the similarity of the zircon grains discovered in the arkositic Korkiavaara Formation and the pelitic Pöyliövaara Formation. Because of the slightly more rounded nature of the Pöyliövaara Formation zircons, rocks of this unit could contain reworked material from the underlying Korkiavaara Formation.

The depositional age of less than 1.98 Ga determined for the Pöyliövaara Formation rises the question about the correlation of this formation with the pelitic metasediments of the Paakkola Group in the west. One problem is posed by the zircon age of 2050 \pm 8 Ma which Perttunen \& Vaasjoki (2001) reported for felsic porphyries occurring in the Väystäjä Formation of the Paakkola Group (see Table 1). These schistose porphyries are interpreted to be effusive in origin and interestingly, exhibit geochemical characteristics similar to those of the arkosites but without a negative Nb-Ta anomaly (see inset in Fig. 7a). They constrain the age of the Väystäjä Formation at ca. 2050 Ma. This formation, which is composed mainly of mafic volcanic rocks and dolomites, is placed above the Martimo Formation in Table 1. This would imply that the Martimo Formation is older than $2050 \mathrm{Ma}$ and hence not correlative to the Pöyliövaara Formation. One solution to this dilemma would be that the Väystäjä Formation is an allochthonous unit having tectonic contacts with the Martimo Formation. The other option is that the Martimo and Pöyliövaara Formations are really different in age with the former representing "lower Kalevian" and the latter "upper Kalevian” rocks.

Regardless of the origin of the arkosites, they indicate that a large amount of granitic magma was produced at ca. 1.98 Ga. Given the likelihood of a Paleoproterozoic A-type granitic source for the arkositic rocks (if interpreted as epiclastic rocks), we should try to locate potential candidates for this source in the presently exposed bedrock in Finland. Some small, A-type granitic bodies have been found in the Archean basement complex, associated with mafic lay- ered intrusions (Lauri \& Mänttäri, 2002). However, they are volumetrically minor and their age, ca. $2.44 \mathrm{Ga}$, is clearly older than that of the zircons in the arkosites. Younger felsic magmatism related to the Svecofennian Domain in southern Finland contains A-type granites, of which the anorogenic rapakivi granites are the most well-known, but they are distinctly younger, ca. 1.65-1.54 Ga old (Haapala \& Rämö, 1991). There exist some older A-type granites among the post-kinematic plutons of the Central Finland Granitoid Complex which have been dated at 1.89-1.87 Ga (Nironen et al., 2000) but they are too young for being involved in the genesis of the Peräpohja Schist Belt arkosites.

Syn- to postkinematic felsic magmatism in northern Finland ranges in age from ca. 1.89 to $1.77 \mathrm{Ga}$ (Hanski et al., 2001). There are some older granodioritic plutons with an age of ca. 1.92 Ga and an enigmatic, relatively old group of granites yielding an age of ca. 2.1 Ga (Rastas et al., 2001), but so far, no ages of felsic plutons close to $1.97 \mathrm{Ga}$ have been reported. Consequently, wide-spread granites with an age of ca. 1.97 Ga seem to be lacking in Finland and the whole Fennoscandian Shield, though some granitoids in central Sweden reach an age of ca. 1.96 Ga (Eliasson \& Sträng, 1998; Wasström, 1993). The only presently known example of a Finnish granitoid with a proper age is found in the Otanmäki area south of the Jormua Ophiolite Complex in eastern Finland, where ID-TIMS U-Pb analyses on zircon have yielded ages of ca. $1.97 \mathrm{Ga}$ (M. Vaasjoki, pers. comm. 1995). However, the geographical extent of these granitoids is unclear, as an age of $2019 \pm 3 \mathrm{Ma}$ has also been obtained for the so-called Otanmäki alkali gneiss from the same area (Hytönen \& Hautala, 1985). The gneiss covers a relatively limited area of ca. $20 \mathrm{~km}^{2}$ within the Archean basement. This fact together with the peralkalic nature of the gneiss suggests that it hardly served as provenance for the detrital material of the Peräpohja Schist Belt arkosites. Nevertheless, it gives an indication of the existence of roughly coeval felsic A-type magmatism.

Although felsic plutonic rocks with an age of 1.95-2.0 Ga seem to be more or less absent in Fin- 
land and elsewhere in the Fennoscandian Shield, this period of time produced mafic rocks related to the formation of new oceanic crust exposed now as volcanic and intrusive rocks of the Jormua and Outokumpu ophiolitic complexes in eastern Finland (Peltonen et al., 1996) and the Kittilä Group in Finnish Lapland (Lehtonen et al., 1998). Meanwhile, the continental areas were not completely inactive as evidenced by the eruption, at ca. $1.98 \mathrm{Ga}$, of the Onega plateau flood basalts in Russian Karelia (Puchtel et al., 1999) and the Pilgujärvi Formation basalts in the Pechenga area (Hanski et al., 1990), though the exact tectonic setting of the upper part of the Pechenga Group is still somewhat controversial. It is noteworthy that in the middle of a thick suite of marine basaltic volcanic rocks of the Pilgujärvi Formation, there exists a thin interlayer of felsic supracrustal rocks which have been called felsic and ultrafelsic tuffs (Zagorodny et al., 1989) or dacitic and rhyolitic porphyries (Rusanov, 1981). These rocks have trace element characteristics akin to those of $A_{1}$-type granites, including high contents of $\mathrm{Zr}, \mathrm{Nb}$, and LREE (Hanski, 1992). These peculiar rocks provide an additional indication of ca. $1.98 \mathrm{Ga}$ A-type magmatism but do not help in solving our arkosite problem as they are minor in volume, have a marine setting and controversial origin: their generation has been attributed to volcanic (Rusanov, 1981), sedimentary (Borisov \& Smolkin, 1992), or meteorite impact-related processes (Jones et al., 2003).

The above mentioned ca. 2.0 Ga mafic magmatic events are manifestations of extensional tectonic processes occurring either in an oceanic or a continental environment. Generation of felsic A-type magmas has often been attributed to an extensional intracratonic, anorogenic setting (e.g., Eby, 1990). In this light, the generation at ca. $1.98 \mathrm{Ga}$ of the felsic magmas which later produced, directly or indirectly, the arkosites of the Peräpohja Schist Belt is well conceivable.

Significant evidence for the generation of felsic igneous rocks at ca. $1.98 \mathrm{Ga}$ is provided by abundant detrital zircons of that age discovered in the Svecofennian and "upper Kalevian" metasediments (Huhma et al., 1991; Claesson et al., 1993; Lahtinen et al., 2002; Rutland et al., 2001, 2004). The sources for this material have remained enigmatic and one may speculate whether they were somehow related to the 1.98 Ga A-type magmatism discussed in this study.

The geochemistry and isotope composition of the arkosites rule out the derivation of felsic magma via direct fractional crystallization of an uncontaminated mantle magma. Instead, based on the relatively high contents of $\mathrm{K}, \mathrm{Ba}, \mathrm{HREE}$, and $\mathrm{Y}$ and low contents of $\mathrm{Sr}$ and $\mathrm{Ca}$ in the arkosite samples, the magma was probably produced by anatexis at mid-crustal levels with residual plagioclase but without residual garnet left in the source.

Which were then the potential tectonic processes causing the major crustal melting event(s) that were able to generate A-type granitic magmas? In the absence of any concrete evidence for other coeval geological events, we suggest that they were linked to the same ca. 1.98 Ga mantle plume upwelling which Walker et al. (1997) and Puchtel et al. (1999) evoked to explain the generation of the Pechenga and Onega mafic to ultramafic magmas. A model often used in accounting for bimodal anorogenic magmatism envisages upwelling of hot asthenosphere and underplating of mafic magmas which trigger partial melting in the lower crust.

In summary, the arkositic rocks occurring in the $\mathrm{N}$ and NE part of the Peräpohja Schist Belt exhibit geochemical characteristics similar to those of $\mathrm{A}_{2}-$ type granites. Assuming an epiclastic origin, they were derived from a source dominated by granites of that kind. Zircons extracted from two arkosite samples and one mica schist sample seem to form a single age population with a mean age of $1975 \pm 10$ $\mathrm{Ma}$, contrasting with the Archean zircons found in a mica schist sample from the western part of the schist belt. The bimodal arkosite-amphibolite suite thus appears to represent the youngest supracrustal rocks in the Peräpohja Schist Belt and record a previously unknown event of extensive $\mathrm{A}_{2}$-type felsic magmatism at ca. $1.98 \mathrm{Ga}$, though felsic plutonic rocks of this age are virtually lacking in the presently exposed Fennoscandian Shield. 


\section{Acknowledgements}

The Nordic geological ion-microprobe facility (NORDSIM) is operated and funded under an agreement between the respective research funding agencies of Denmark, Norway and Sweden, the Geological Survey of Finland, and the Swedish Museum of Natural History. This paper is NORDSIM contribution No. 110. We are grateful to Martin Whitehouse for providing assistance during the SIMS work. We also want to thank Torbjörn Skiöld, Kåre Kullerud, and Laura Lauri for valuable comments on the original manuscript.

\section{References}

Bonjour, J.-L. \& Dabard, M.-P., 1991. Ti/Nb ratios of clastic terrigenous sediments used as an indicator of provenance. Chemical Geology 91, 257-267.

Borisov, A.E. \& Smolkin, V.F., 1992. On the problem of the genesis of high-silica formations of the fourth volcanic unit of the Pechenga structure. Izvestiya Akademiya Nauk, Seriya Geologicheskaya No. 7, 66-78. (in Russian)

Claesson, S., Huhma, H., Kinny, P. \& Williams, I., 1993. Svecofennian detrital zircon ages - implications for the Precambrian evolution of the Baltic Shield. Precambrian Research 64, 109-130.

Debon, F.P. \& Le Fort, P., 1983. A chemical mineralogical classification of common plutonic rocks and associations. Transactions of the Royal Society of Edinburgh, Earth Science 73, 135-149.

DePaolo, D.J., 1981. Neodymium isotopes in the Colorado Front Range and crust-mantle evolution in the Proterozoic. Nature 291, 684-687.

Eby, G.N., 1990. The A-type granitoids: A review of their occurrence and chemical characteristics and speculations on their petrogenesis. Lithos 26, 155-134.

Eby, G.N., 1992. Chemical subdivision of A-type granites: Petrogenetic and tectonic implications. Geology 20, 641-644.

Eliasson, T. \& Sträng, T., 1998. Kartbladen 23 H, Stensele. Swedish Geological Survey, Rapporter och Meddelanden 97, 55-59.

Haapala, I. \& Rämö, O.T., 1992. Tectonic setting and origin of the Proterozoic rapakivi granites of southeastern Fennoscandia. Transactions of the Royal Society of Edinburgh - Earth Science 83, 165-171.

Hanski, E., 1992. Petrology of the Pechenga ferropicrites and cogenetic, Ni-bearing gabbro-wehrlite intrusions, Kola Peninsula, Russia. Geological Survey of Finland, Bulletin 367, 192 p.

Hanski, E., 2001. History of stratigraphical research in northern Finland. In: Vaasjoki, M. (ed.) Radiometric age determinations from Finnish Lapland and their bearing on the timing of Precambrian volcano-sedimenta- ry sequences. Geological Survey of Finland, Special Paper 33, 15-43.

Hanski, E., 2002. Vikajärvi. Geological map of Finland 1:100 000, pre-Quaternary rocks, sheet 3614, Geological Survey of Finland.

Hanski, E., Huhma, H., Smolkin, V.F. \& Vaasjoki, M., 1990. The age of the ferropicritic volcanics and comagmatic Ni-bearing intrusions at Pechenga, Kola Peninsula. Bulletin of the Geological Society of Finland 62, 123-133.

Hanski, E., Huhma, H. \& Vaasjoki, M., 2001. Geochronology of northern Finland: a summary and discussion. In: Vaasjoki, M. (ed.) Radiometric age determinations from Finnish Lapland and their bearing on the timing of Precambrian volcano-sedimentary sequences. Geological Survey of Finland, Special Paper 33, 255-279.

Härme, M., 1949. On the stratigraphical and structural geology of the Kemi area, northern Finland. Bulletin de la Commission géologique de Finlande 147, 60 p.

Huhma, H., 1986. Sm-Nd, U-Pb and Pb-Pb isotopic evidence for the origin of the Early Proterozoic Svecokarelian crust in Finland. Geological Survey of Finland, Bulletin $337,48 \mathrm{p}$.

Huhma, H., 1987. Provenance of early Proterozoic and Archaean metasediments in Finland: a Sm-Nd isotopic study. Precambrian Research 35, 127-143.

Huhma, H., Cliff, R.A., Perttunen, V. \& Sakko, M., 1990. $\mathrm{Sm}-\mathrm{Nd}$ and $\mathrm{Pb}$ isotopic study of mafic rocks associated with early Proterozoic continental rifting: the Peräpohja schist belt in northern Finland. Contributions to Mineralogy and Petrology 104, 369-379.

Huhma, H., Claesson, S., Kinny, P.D. \& Williams, I.S. 1991. The growth of Early Proterozoic crust: new evidence from Svecofennian detrital zircons. Terra Nova 3, 175-178.

Hytönen, K. \& Hautala, T. 1985. Aegirine and riebeckite of the alkali gneiss of Pikkukallio in the Honkamäki-Otanmäki region, Finland. Bulletin of the Geological Society of Finland 57, 169-180.

Jones, A.P., Mutanen T., Tuisku, P., Hanski, E. \& Price, G.D., 2003. The Pechenga structure, Russia: giant Ni$\mathrm{Cu}$ mineralisation related to large meteorite impact? Fermor Flagship Meeting "World class mineral deposits and Earth evolution”, August 19-21, 2003, Cardiff University and The National Museum of Wales, Abstracts, Applied Earth Science. Transactions of the Institution of Mining and Metallurgy, Section B 112, B149-150.

Karhu, J., 1993. Paleoproterozoic evolution of the carbon isotope ratios of sedimentary carbonates in the Fennoscandian Shield. Geological Survey of Finland, Bulletin 371, 87 p.

Karhu, J.A., 2005. Paleoproterozoic carbon isotope excursion. In: Lehtinen, M., Nurmi, P.A. \& Rämö, O.T. (eds.) Precambrian Geology of Finland - Key to the Evolution of the Fennoscandian Shield. Elsevier Science B.V., Amsterdam, 669-684. 
Lahtinen, R., Huhma, H. \& Kousa, J., 2002. Contrasting source components of the Paleoproterozoic Svecofennian metasediments: Detrital zircon U-Pb, Sm-Nd and geochemical data. Precambrian Research 116, 81-109.

Lauerma, R., 1982. On the ages of some granitoid and schist complexes in Northern Finland. Bulletin of the Geological Society of Finland 54, 85-100.

Lauri, L.S. \& Mänttäri, I., 2002. The Kynsijärvi quartz alkali feldspar syenite, Koillismaa, eastern Finland - silicic magmatism associated with $2.44 \mathrm{Ga}$ continental rifting. Precambrian Research 119, 121-140.

Lehtonen, M., Airo, M-L., Eilu, P., Hanski, E., Kortelainen, V., Lanne, E., Manninen, T., Rastas, P., Räsänen, J. \& Virransalo, P., 1998. Kittilän vihreäkivialueen geologia. Summary: The stratigraphy, petrology and geochemistry of the Kittilä greenstone area, Northern Finland. Geological Survey of Finland, Report of Investigation $140,144 \mathrm{p}$.

Ludwig, K.R., 2001. Users Manual for Isoplot/Ex rev. 2.49. Berkeley Geochronological Center, Special Publication No. 1a, 55 p.

McCulloch, M.T. \& Wasserburg, G.J., 1978. Sm-Nd and $\mathrm{Rb}-\mathrm{Sr}$ chronology of continental crust formation. Science 200, 1003-1011.

Meriläinen, K., 1980. Stratigraphy of the Precambrian in Finland. Geologiska Föreningens i Stockholm Förhandlingar 102, 177-180.

Niiranen, T., Hanski \& E., Eilu, P., 2003. General geology, alteration, and iron deposits in the Palaeoproterozoic Misi region, northern Finland. Bulletin of the Geological Society of Finland 75, 69-92.

Nironen, M., Elliott, B.A. \& Rämö, O.T., 2000. 1.881.87 Ga post-kinematic intrusions of the Central Finland Granitoid Complex: a shift from C-type to A-type magmatism during lithospheric convergence. Lithos 53, 37-58.

O’Brien, H., Huhma, H. \& Sorjonen-Ward, P., 1993. Petrogenesis of the late Archean Hattu schist belt, Ilomantsi, eastern Finland: geochemistry and $\mathrm{Sr}, \mathrm{Nd}$ isotopic composition. In: Nurmi, P. A., Sorjonen-Ward, P. (eds.) Geological development, gold mineralization and exploration methods in the late Archean Hattu Schist Belt, Ilomantsi, Eastern Finland. Geological Survey of Finland, Special Paper 17, 147-184.

Pearce, J.A., Harris, N.B.W. \& Tindle, A.G., 1984. Trace element discrimination diagrams for the tectonic interpretation of granitic rocks. Journal of Petrology 25, 956-983.

Peltonen, P., Kontinen, A. \& Huhma, H., 1996. Petrology and geochemistry of metabasalts from the 1.95 Ga Jormua Ophiolite, northeastern Finland. Journal of Petrology 37, 1359-1383.

Perttunen, V., 1980. Stratigraphy of the Peräpohja schist area. In: Silvennoinen, A. (ed.) Jatulian Geology in the Eastern Part of the Baltic Shield. Proceedings of a Finnish-Soviet Symposium held in Finland, $21^{\text {st }}-26^{\text {th }}$ August 1979, Rovaniemi. Rovaniemi: The Committee for Sci- entific and Technical Co-operation between Finland and the Soviet Union, 139-144.

Perttunen, V., 1985. On the Proterozoic stratigraphy and exogenic evolution of the Peräpohja area, Finland. In: Laajoki, K., Paakkola, J. (eds.) Proterozoic Exogenic Processes and Related Metallogeny. Geological Survey of Finland, Bulletin 331, 131-141.

Perttunen, V., 1989. Peräpohjan alueen vulkaniitit. Lapin vulkaniittiprojektin raportti. Summary: Volcanic rocks in the Peräpohja area, northern Finland. A report of the Lapland Volcanite Project. Geological Survey of Finland, Report of Investigation 92, 40 p.

Perttunen, V., 1991. Kemi, Karunki, Simo and Runkaus. Explanation to the Geological map of Finland 1:100 000 , pre-Quaternary rocks, sheets $2541,2542+2524$, 2543 and 2544. Geological Survey of Finland, 80 p. (in Finnish with English summary).

Perttunen, V., 2002. Törmäsjärvi. Geological map of Finland 1:100 000, pre-Quaternary rocks, Sheet 2631, Geological Survey of Finland.

Perttunen, V. \& Hanski, E., 2003. Koivu and Törmäsjärvi. Explanation to the Geological map of Finland 1:100 000, pre-Quaternary rocks, sheets 3631 and 2633. Geological Survey of Finland, 88 p. (in Finnish with English summary).

Perttunen, V. \& Vaasjoki, M., 2001. U-Pb geochronology of the Peräpohja Schist Belt, northwestern Finland. In: Vaasjoki, M. (ed.) Radiometric age determinations from Finnish Lapland and their bearing on the timing of Precambrian volcano-sedimentary sequences. Geological Survey of Finland, Special Paper 33, 45-84.

Perttunen, V., Hanski, E. \& Väänänen, J., 1995. Stratigraphical map of the Peräpohja Schist Belt, northern Finland. In: Kohonen, T., Lindberg, B. (eds.) The $22^{\text {nd }}$ Nordic Geological Winter Meeting, 8-11 January 1996, Turku, Abstracts of oral and poster presentations, p. 152.

Perttunen, V., Hanski, E., Väänänen, J., Eilu, P. \& Lappalainen, M., 1996. Rovaniemi. Explanation to the Geological map of Finland 1:100 000, Pre-Quaternary rocks, sheet 3612, Geological Survey of Finland, 63 p. (in Finnish with English summary).

Pettijohn, F.J., 1975. Sedimentary Rocks. Harper \& Row, New York, 628 p.

Puchtel, I.S., Brügmann, G.E. \& Hofmann, A.W., 1999. Precise $\mathrm{Re}-\mathrm{Os}$ mineral isochron and $\mathrm{Pb}-\mathrm{Nd}-\mathrm{Os}$ isotope systematics of a mafic-ultramafic sill in the $2.0 \mathrm{Ga} \mathrm{On}$ ega plateau (Baltic Shield). Earth and Planetary Science Letters 170, 447-461.

Rastas, P., Huhma, H., Hanski, E., Lehtonen, M.I., Paakkola, J., Mänttäri, I. \& Härkönen, I., 2001. U-Pb isotopic studies on the Kittilä greenstone area, Central Lapland, Finland. In: Vaasjoki, M. (ed.) Radiometric Age Determinations from Finnish Lapland and Their Bearing on the Timing of Precambrian Volcano-Sedimentary Sequences. Geological Survey of Finland, Special Paper 33, 95-141. 
Richard, P., Shimizu, N. \& Allègre, C.J., $1976 .{ }^{143} \mathrm{Nd} /{ }^{146} \mathrm{Nd}$, a natural tracer: an application to oceanic basalts. Earth and Planetary Science Letters 31, 269-278.

Rusanov, M.S., 1981. Tholeiitic-komatiitic formations of the Pechenga Complex. Sovietskaya Geologiya No. 2, 98-112. (in Russian)

Rutland, R.W.R., Skiöld, T. \& Page, R.W. 2001. Age of deformation episodes in the Palaeoproterozoic domain of northern Sweden, and evidence for a pre-1.9 Ga crustal layer. Precambrian Research 112, 239-259.

Rutland, R.W.R., Williams, I.S. \& Korsman, K. 2004. Pre1.9 Ga deformation and metamorphism in the Palaeoproterozoic Vammala Migmatite Belt, southern Finland, and implications for Svecofennian tectonics. Bulletin of the Geological Society of Finland 76, 93-140.

Salonsaari, P., 1990. Vanttauskosken alueen kallioperän deformaatio. M.Sc. Thesis, University of Oulu, Finland, $62 \mathrm{p}$.

Stacey, J.S. \& Kramers, J.D., 1975. Approximation of terrestrial lead isotope evolution by a two-stage model. Earth and Planetary Science Letters 26, 207-221.

Sun, S.-S. \& McDonough, W. F., 1989. Chemical and isotopic systematics of oceanic basalts; implications for mantle composition and processes. In: Saunders, A. D., Norry, M. J. (eds.) Magmatism in the Ocean Basins. Geological Society, Special Publication 42, 313-345.

Väänänen, J., Hanski, E. \& Perttunen, V., 1997. Rovaniemi. Geological map of Finland 1:100 000, pre-Quaternary rocks, sheet 3612, Geological Survey of Finland.

Walker, R.J., Morgan, J.W., Hanski, E.J. \& Smolkin, V.F., 1997. Re-Os systematics of early Proterozoic ferropicrites, Pechenga Complex, Russia: evidence for ancient ${ }^{187} \mathrm{Os}$ enriched plumes. Geochimica et Cosmochimica Acta 61, 3145-3160.
Wasserburg, G.J., Jacobsen, S.B., DePaolo, D.J., McCulloch, M.T. \& Wen, T., 1981. Precise determination on $\mathrm{Sm} / \mathrm{Nd}$ ratios, $\mathrm{Sm}$ and $\mathrm{Nd}$ isotopic abundances in standard solutions. Geochimica et Cosmochimica Acta 45, 2311-2323.

Wasström, A., 1993. The Knaften granitoids of Vasterbotten County, northern Sweden. In: Lunqvist, T. (ed.) Radiometric Dating Results. Geological Survey of Sweden, series C, vol. 823, 60-64.

Whalen, J.B., Currie, K.L. \& Chappel, B.W., 1987. A-type granites: geochemical characteristics, discrimination and petrogenesis. Contributions to Mineralogy and Petrology $95,407-419$.

Whitehouse, M., Claesson, S., Sunde, T. \& Vestin, J., 1997. Ion microprobe $\mathrm{U}-\mathrm{Pb}$ zircon geochronology and correlation of Archaean gneisses from the Lewisian Complex of Gruinard Bay, northwestern Scotland. Geochimica et Cosmochimica Acta 61, 4429-4438.

Whitehouse, M.J., Kamber, B.S. \& Moorbath, S., 1999. Age significance of U-Th-Pb zircon data from early Archaean rocks of west Greenland - a reassessment based on combined ion-microprobe and imaging studies. Chemical Geology 160, 201-224.

Wiedenbeck, M., Allé, P., Corfu, F., Griffin, W.L., Meier, M., Oberli, F., von Quadt, A., Roddick, J.C. \& Spiegel, W., 1995. Three natural zircon standards for U-Th-Pb, Lu-Hf, trace element and REE analysis. Geostandards Newsletter 19, 1-23.

Zagorodny, V.G., Melezhik, V.A. \& Lyubtsov, V.V., 1989. Correlation of early Proterozoic complexes of PolmakPasvik-Pechenga. Guidebook to geological excursions in Pechenga region. Geological Institute, Kola Science Center, USSR Academy of Sciences, Apatity, 38 p. 